\title{
Pharmacotherapies for Obesity: Past, Current, and Future Therapies
}

\author{
Lisa L. Ioannides-Demos, Loretta Piccenna, and John J. McNeil \\ Department of Epidemiology and Preventive Medicine, School of Public Health and Preventive Medicine, Monash University, \\ Alfred Centre, Commercial Road, Melbourne, VIC 3004, Australia \\ Correspondence should be addressed to Lisa L. Ioannides-Demos, lisa.demos@monash.edu
}

Received 4 August 2010; Accepted 24 September 2010

Academic Editor: A. Halpern

Copyright ( 92011 Lisa L. Ioannides-Demos et al. This is an open access article distributed under the Creative Commons Attribution License, which permits unrestricted use, distribution, and reproduction in any medium, provided the original work is properly cited.

\begin{abstract}
Past therapies for the treatment of obesity have typically involved pharmacological agents usually in combination with a caloriecontrolled diet. This paper reviews the efficacy and safety of pharmacotherapies for obesity focusing on drugs approved for longterm therapy (orlistat), drugs approved for short-term use (amfepramone [diethylpropion], phentermine), recently withdrawn therapies (rimonabant, sibutamine) and drugs evaluated in Phase III studies (taranabant, pramlintide, lorcaserin and tesofensine and combination therapies of topiramate plus phentermine, bupropion plus naltrexone, and bupropion plus zonisamide). No current pharmacotherapy possesses the efficacy needed to produce substantial weight loss in morbidly obese patients. Metaanalyses support a significant though modest loss in bodyweight with a mean weight difference of $4.7 \mathrm{~kg}$ (95\% CI 4.1 to $5.3 \mathrm{~kg})$ for rimonabant, $4.2 \mathrm{~kg}$ (95\% CI 3.6 to $4.8 \mathrm{~kg}$ ) for sibutramine and $2.9 \mathrm{~kg}$ ( $95 \%$ CI 2.5 to $3.2 \mathrm{~kg}$ ) for orlistat compared to placebo at $\geq 12$ months. Of the Phase III pharmacotherapies, lorcaserin, taranabant, topiramate and bupropion with naltrexone have demonstrated significant weight loss compared to placebo at $\geq 12$ months. Some pharmacotherapies have also demonstrated clinical benefits. Further studies are required in some populations such as younger and older people whilst the long term safety continues to be a major consideration and has led to the withdrawal of several drugs.
\end{abstract}

\section{Introduction}

Management strategies for weight reduction in obese individuals include physical interventions such as exercise, diet, and surgery, behavioural therapies, and pharmacological treatments. These strategies may be used alone or in combination for greater efficacy. Most randomized controlled trials (RCTs) evaluating pharmacotherapies include a caloriecontrolled diet, and some also encourage participants to increase their physical activity.

Drugs used to induce weight loss may reduce appetite or increase satiety, reduce the absorption of nutrients, or increase energy expenditure. Weight loss with pharmacotherapies is generally modest, that is, usually 2 to $7.9 \mathrm{~kg}$ more than that achieved with placebo treatment [1]. In the past drug therapies available have included thyroid hormone, dinitrophenol and amphetamines, followed by amphetamine analogues, aminorex, and the fenfluramines [1]. More recently a number of newer agents have been trialed though only orlistat and sibutramine were approved for longterm use ( $\geq 24$ weeks). Following the recent withdrawal of sibutramine this leaves only orlistat (Table 1 ).

Amongst the drugs marketed for weight loss there have been several instances of market withdrawal due to serious adverse events. The agents involved include dinitrophenol, aminorex, the fenfluramines, phenylpropanolamine and most recently rimonabant. Other drugs such as the amphetamines are severely restricted due to their abuse potential. Fenfluramine and dexfenfluramine were recalled from the world market in 1997 due to concerns of an increased prevalence of valvular heart disease, and the possible association with primary pulmonary hypertension [26]. In April 2000, the European Medicines Agency (EMEA) recommended the withdrawal of several weight loss drugs from the market including phentermine, amfepramone (diethylpropion) and mazindol due to an unfavourable risk 
TABLE 1: Drugs used for weight loss in obesity.

\begin{tabular}{|c|c|c|c|}
\hline Drug & Introduced & Mechanism of action & Status \\
\hline Dinitrophenol & $1930 \mathrm{~s}$ & Increases metabolic rate & $\begin{array}{l}\text { Withdrawn-risk of neuropathy and } \\
\text { cataracts }\end{array}$ \\
\hline $\begin{array}{l}\text { Amphetamines: } \\
\text { dexamphetamine, } \\
\text { methamphetamine }\end{array}$ & 1936 & Appetite suppression & $\begin{array}{l}\text { Banned, restricted or } \\
\text { discouraged-dependency and abuse } \\
\text { potential, cardiovascular adverse effects }\end{array}$ \\
\hline \multirow{3}{*}{$\begin{array}{l}\text { Amphetamine-like } \\
\text { analogues: Phentermine, } \\
\text { diethylpropion, } \\
\text { phenylpropanolamine }\end{array}$} & \multirow[t]{3}{*}{ 1959-US } & \multirow[t]{3}{*}{ Appetite suppression } & $\begin{array}{l}\text { Diethylpropion-available for short-term } \\
\text { use ( } \leq 12 \text { weeks })\end{array}$ \\
\hline & & & $\begin{array}{l}\text { Phentermine-available for short-term } \\
\text { use ( } \leq 12 \text { weeks) in some countries, } \\
\text { withdrawn } 2000 \text { (UK) }\end{array}$ \\
\hline & & & $\begin{array}{l}\text { Phenylpropanolamine-withdrawn } \\
2000 \text {-increased risk haemorrhagic } \\
\text { stroke }\end{array}$ \\
\hline Aminorex & 1965 & Appetite suppression & $\begin{array}{l}\text { Withdrawn 1968-pulmonary } \\
\text { hypertension }\end{array}$ \\
\hline Mazindol & 1970 s & Appetite suppression & Discontinued 1993-Australia \\
\hline Fenfluramine & $\begin{array}{l}\text { 1963-Europe } \\
\text { 1973-US }\end{array}$ & Appetite suppression & $\begin{array}{l}\text { Withdrawn 1997—valvular heart disease, } \\
\text { pulmonary hypertension }\end{array}$ \\
\hline Dexfenfluramine & $\begin{array}{l}\text { 1985-Europe } \\
\text { 1996-US }\end{array}$ & Appetite suppression & $\begin{array}{l}\text { Withdrawn } 1997 \text { - valvular heart disease, } \\
\text { pulmonary hypertension }\end{array}$ \\
\hline Orlistat & $\begin{array}{l}\text { 1998-Europe } \\
\text { and US }\end{array}$ & Decreased fat absorption & $\begin{array}{l}\text { Also available over-the-counter in several } \\
\text { countries }\end{array}$ \\
\hline \multirow{3}{*}{ Sibutramine } & \multirow[t]{3}{*}{$\begin{array}{l}\text { 1997-US } \\
\text { 2001-Europe }\end{array}$} & \multirow[t]{3}{*}{ Appetite suppression } & $\begin{array}{l}\text { Temporarily withdrawn } 2002 \\
\text { Italy-concerns of raised risk of heart } \\
\text { attacks and strokes }\end{array}$ \\
\hline & & & $\begin{array}{l}\text { Increase in contraindications } 2010 \text {-US, } \\
\text { Australia }\end{array}$ \\
\hline & & & Suspension of market authorization 2010 \\
\hline Rimonabant & 2006-Europe & & $\begin{array}{l}\text { Withdrawn 2009-potential of serious } \\
\text { psychiatric disorders }\end{array}$ \\
\hline
\end{tabular}

to benefits ratio [7]. This was followed by the voluntary withdrawal of medications containing phenylpropanolamine due to reports of haemorrhagic stroke in women [8] (Table 1).

Rimonabant was approved as an adjunct to diet and exercise for the treatment of obese or overweight patients by the EMEA in 2006. However the FDA never approved its use in the US due to serious safety concerns. Then in January 2009, the EMEA withdrew market authorisation for rimonabant in all countries of the European Union due to an increased risk of psychiatric adverse events, including depressed mood disorders, anxiety, and suicidal ideation [911]. Concern was recently raised regarding the safety of sibutramine, following earlier reports of increased systolic and diastolic blood pressure and heart rate [10]. With this concern in mind, the safety was investigated in patients with a history of cardiovascular disease in the Sibutramine Cardiovascular Outcomes Trial (SCOUT). The release of preliminary results from SCOUT led to the compulsory inclusion of contraindications and precautions in the US and Australian product information, whilst the EMEA recommended total suspension of market authorisation for the drug in Europe [12-16]. Following the subsequent publication of the SCOUT study [17] the FDA considered whether to severely restrict access to the sibutramine or remove it from the market. Sibutramine was subsequently withdrawn by the manufacturer.

Some drugs which had demonstrated positive weight loss potential such as taranabant have been abandoned during late phase clinical trials due to unacceptable adverse events. Whilst axokine, a ciliary neurotrophic factor that was administered as a daily subcutaneous injection, was abandoned due to the low percentage of responders as a result of the development of antibodies in the majority of patients taking the drug [18].

The efficacy and safety of long-term drug therapy is a very important consideration in the management obesity which often requires ongoing therapy to achieve and maintain the weight loss. This paper provides a review of the efficacy and safety of drug therapies for weight loss with at least six months of patient follow-up focusing on randomised controlled trials (RCTs) published over the last 4 years of recent past and current pharmacotherapies, as well as those in late phase clinical trials. 


\section{Measuring Effectiveness of Drug Therapy}

There are some challenges in establishing the medium and longer-term efficacy of pharmacotherapies designed to induce weight loss. These include the continuance of patients throughout the entire study duration and the likelihood that patients who report more weight loss will be more likely to complete the study. In an effort to control bias from this source the use of last observation carried forward is commonly used to approximate weight loss for the patients withdrawing from a study $[7,19,20]$.

There is also some controversy as to which primary outcome measures are best to evaluate the efficacy of drug therapies, that is, absolute weight loss (in excess of placebo), percentage weight loss, percentage of patients achieving $\geq 5 \%$ or $\geq 10 \%$ weight loss of initial weight, BMI, or waist circumference (WC). The length of time over which weight loss is sustained is also important which implies prolonged follow-up, at least twelve months or if possible longer. In studies involving children, the BMI appears to be the most appropriate measure of effectiveness [21]. Secondary efficacy endpoints are increasingly reported especially in more recent studies, and these include clinical measures such as blood pressure, glycaemic control (blood glucose or $\mathrm{HbA1C}$ levels) and cholesterol levels [14, 22, 23].

\section{Past Drug Therapies and Current Approved Drugs}

Drugs that have been prescribed or evaluated for obesity may reduce fat absorption or regulate satiety via their action on serotonin, noradrenergic or dopaminergic or the cannabinoid receptor systems in the brain (Table 2) $[1,3,24-26]$.

3.1. Amphetamines and Amphetamine-Like Analogues. Amphetamines and amphetamine-like analogues (phentermine, diethylpropion, phenylpropanolamine) are indirect-acting sympathomimetic agents that act by releasing noradrenaline (NA) from presynaptic vesicles in the lateral hypothalamus [1]. Mazindol, a related but discontinued drug, blocks the reuptake of NA by presynaptic neurons (Table 2) [1]. The increase in NA concentration within the synaptic cleft results in the stimulation of $\beta 2$-adrenergic receptors and a resultant inhibition of appetite.

There is little data from large randomized controlled trials (RCTs) relating to the long-term efficacy or safety of amphetamines and amphetamine-like analogues, especially when used as monotherapy. These drugs have limited use in the routine management of obesity and are not currently approved for long-term use. Phentermine has been available since the late 1950s and is approved for short-term use in the US and Australia (Table 2). It has been evaluated as both monotherapy and as combination therapy though not in large-scale studies [27, 28]. A 36-week RCT in 108 overweight women demonstrated a mean weight loss of $12.2 \mathrm{~kg}$ (13\%) with phentermine (30 mg daily) compared to $4.8 \mathrm{~kg}$ $(5.2 \%)$ with placebo $(P<.001)$. Phentermine has been used in combination with fenfluramine and with fluoxetine [29].
Combination therapy with phentermine $(15 \mathrm{mg})$ and fenfluramine $(60 \mathrm{mg})$, demonstrated significantly more weight loss than placebo in a 28 -week RCT $(15.5 \%$ versus $4.9 \%$, $P<$.001) [28]. Phentermine is currently under evaluation in combination with topiramate and with pramlintide (see Drug Monotherapies and Combination Therapies in Clinical Development).

3.1.1. Diethylpropion (amfepramone). another amphetamine-like analogue has been available for weight loss since the early 1960s; however there are few if any RCTs of its long-term use especially with large sample sizes $[30,31]$. Diethylpropion ( $75 \mathrm{mg}$ daily) demonstrated significantly greater weight loss in a small 24 -week study of 20 patients than placebo (11.6 kg versus $2.5 \mathrm{~kg}, P<.01$ ) [31]. Recently, diethylpropion ( $50 \mathrm{mg}$ twice a day) was shown to be more effective than placebo in a small 6-month RCT with 69 obese adult patients $(9.3 \mathrm{~kg}$ [95\% CI $7-11.5 \mathrm{~kg}]$ versus $3.1 \mathrm{~kg}$ [95\% CI $1.8-4.3 \mathrm{~kg}$ ], $P<.0001$ ) [32]. Greater than $5 \%$ weight loss was achieved in $67.6 \%$ of diethylpropion patients and $25.0 \%$ of those receiving placebo $(P=.0005)$. After further 6 months during an open label period of the study patients who were originally in the diethylpropion group lost a mean of $10.1 \mathrm{~kg}$ (95\% CI 7.5-12.8). The most common side effects were dry mouth and insomnia $(P=.02$ and $P=.009$, respectively). These were experienced in the first 3 months but become less apparent with continuing treatment [32].

3.2. Fenfluramines. Fenfluramine and dexfenfluramine elevate serum levels of serotonin (5HT) in the central nervous system by stimulating $5 \mathrm{HT}$ release and inhibiting its reuptake (Figure 1). Increased levels of 5HT appear to stimulate the hypothalamus, which controls satiation as well as mood, sleep, body temperature and other vital functions. These agents also activate melanocortin 4 receptors that in turn stimulate activation of 5-HT2C receptors, producing an increased release of 5HT within the hypothalamic-pituitaryadrenal axis which is claimed to lead to hypophagia and anorexia [33-36].

A meta-analysis of RCTs with fenfluramine and dexfenfluramine demonstrated higher weight loss than placebo following up to 12 months of treatment. The greatest efficacy was shown following 3 months treatment, $3.7 \mathrm{~kg}$ weight loss [37].

Although RCTs with fenfluramines (fenfluramine and dexfenfluramine), either alone $[38,39]$ or with phentermine [40], demonstrated significant weight-loss, they were withdrawn from the market due to increased reports of valvular heart disease and primary pulmonary hypertension $[2,3,29,41-43])$. The prevalence rates of both valvular heart disease and primary pulmonary hypertension were higher following longer exposure to the fenfluramines [3].

\subsection{Antidepressants}

3.3.1. Fluoxetine, Bupropion. Fluoxetine, a selective serotonin reuptake inhibitor (SSRI) that augments 5HT within the central nervous system has been prescribed off-label for weight loss. Although significant weight loss was reported 
TABLE 2: Central mechanisms of action of anti-obesity pharmacotherapies.

\begin{tabular}{|c|c|c|}
\hline Central Subsystem & Drugs targets & $\begin{array}{l}\text { Possible receptor subtypes } \\
\text { involved }\end{array}$ \\
\hline \multirow{7}{*}{$\begin{array}{l}\text { Monoamine system (indirect } \\
\text { agonists and subtype selective } \\
\text { receptor antagonists) }\end{array}$} & Single therapies & \\
\hline & (i) Dex/fenfluramine (WD), fluoxetine & (i) $5 \mathrm{HT}$ \\
\hline & (ii) Phentermine/Diethylpropion (ST) & (ii) $\mathrm{DA}, \mathrm{NA}$ \\
\hline & (iii) Sibutramine & $\begin{array}{l}\text { (iii) } \alpha_{1}, \beta_{1}, \beta_{3} \text { adrenergic and } \\
5 \mathrm{HT}_{2 B / C}\end{array}$ \\
\hline & (iv) Bupropion & (iv) DA, NA \\
\hline & (v) Tesofensine & (v) DA, NA, 5HT \\
\hline & (vi) Lorcaserin & (vi) $5 \mathrm{HT}_{2 \mathrm{C}}$ \\
\hline \multirow{3}{*}{$\begin{array}{l}\text { Opioid system ( } \mu \text {-opioid receptor } \\
\text { antagonist) }\end{array}$} & (i) Naltrexone & (i) $\mu$-opioid \\
\hline & (ii) Topiramate & (ii) AMPA/kainite glutamate* \\
\hline & (iii) Zonisamide & (iii) $5 \mathrm{HT}, \mathrm{DA}^{*}$ \\
\hline \multirow{3}{*}{ Cannabinoid system } & Single therapies: & \\
\hline & (i) Rimonabant (WD) & (i) $\mathrm{CB}_{1}$ \\
\hline & (ii) Taranabant (DC) & (ii) $\mathrm{CB}_{1}$ \\
\hline \multirow{2}{*}{ Monoamine/Opioid system } & Bupropion/naltrexone & (i) DA, NA/ $\mu$-opioid \\
\hline & Bupropion/zonisamide & (ii) DA, NA/5HT, DA* \\
\hline $\begin{array}{l}\text { Neuropeptide Y/Agouti-related } \\
\text { peptide system }\end{array}$ & Pramlintide/metreleptin & $\begin{array}{l}\text { (i) Calcitonin receptor*/Leptin } \\
\text { receptor }\end{array}$ \\
\hline
\end{tabular}

5HT: serotonergic, DA: dopaminergic, NA: noradrenergic, WD:withdrawn; DC: phase III trials discontinued; ST: short term; ${ }^{*}$ unknown; AMPA: $\alpha$-amino3-hydroxyl-5-methyl-4-isoxazole-propionate.

with $60 \mathrm{mg}$ of this agent in short-term studies of 6-8 weeks, with maximum weight loss achieved at 12-20-weeks, this is followed by a regain in bodyweight [44-47]. Most RCTs have not shown a significant difference when fluoxetine was compared to placebo at 52 weeks $[46,48]$. Significantly greater weight loss has however been demonstrated at 8 months when fluoxetine was used in combination with dexfenfluramine (13.4 versus $6.2 \mathrm{~kg}$ with placebo) [49]. In clinical practice fluoxetine $10-20 \mathrm{mg}$ has been used with phentermine (i.e., phen-pro or phen-flu) but there are no RCTs of either the long-term efficacy or safety of this combination [50]. A retrospective chart review suggested this combination is not as effective as fenfluramine with phentermine [51]. Fluoxetine generally has a tolerable safety profile with reported adverse events of headache, asthenia, nausea, diarrhoea, somnolence, insomnia, nervousness, sweating, and tremor [47].

3.3.2. Bupropion. is another antidepressant which inhibits reuptake of dopamine (DA) and noradrenaline (NA) resulting in a loss of appetite and decreased food intake [52] and modest weight loss in obese people [53-56]. The efficacy of bupropion as a sustained release (SR) formulation was demonstrated at 48 weeks in obese patients [53]. Weight loss was dose dependent with $7.5 \%$ initial weight loss for subjects taking $300 \mathrm{mg}$ bupropion-SR and $8.6 \%$ with $400 \mathrm{mg}$ [53]. Bupropion-SR was generally well tolerated, and weight loss was maintained at 48 weeks. A meta-analysis of weight loss treatments which included 5 bupropion studies reported a mean weight loss of $2.8 \mathrm{~kg}(95 \% \mathrm{CI}, 1.1$ to $4.5 \mathrm{~kg}$ ) at 6 to 12 months with bupropion compared to placebo [56] (Table 3). Although bupropion is not approved for weight loss, it has been used off-label and is currently under evaluation as combination therapy with naltrexone, a $\mu$-opioid receptor antagonist and zonisamide, a GABA receptor activator (see Drug Monotherapies and Combination Therapies under Investigation).

3.4. Orlistat. Orlistat (a gastrointestinal lipase inhibitor) is a synthetic drug derived from a naturally occurring lipase inhibitor. It does not directly act on appetite as other obesity pharmacotherapies, rather it decreases fat absorption by binding to pancreatic lipase, the principle enzyme that hydrolyses triglyceride (Table 2) (Figure 1) [26]. A detailed review of the efficacy of orlistat treatment in obesity has previously been described [1]. The long-term efficacy of orlistat (120 mg three times daily) for weight loss has been demonstrated in several RCTs of 2- to 4- year therapy compared to placebo [61-64], as well as improvements in blood pressure, insulin resistance, and serum lipid levels [57, 64-66]. Several systematic reviews in adults [56, 57, 67-70] and a systematic review with 2 short-term studies in adolescents [71] demonstrated significantly more weight loss with orlistat than placebo, $6.2 \mathrm{~kg}$ (95\% CI, 1.7 to $14.0 \mathrm{~kg}$ ).

The most commonly experienced side effects of orlistat are gastrointestinal and include diarrhoea, flatulence, bloating, abdominal pain, and dyspepsia [25, 66, 70]. Recently, severe liver injury has been reported. The FDA received 32 reports of serious liver injury in patients using orlistat between 1999 and October 2008, including 6 cases of liver failure [72]. This prompted the FDA to undertake a review of the safety of orlistat treatment. The review identified a 


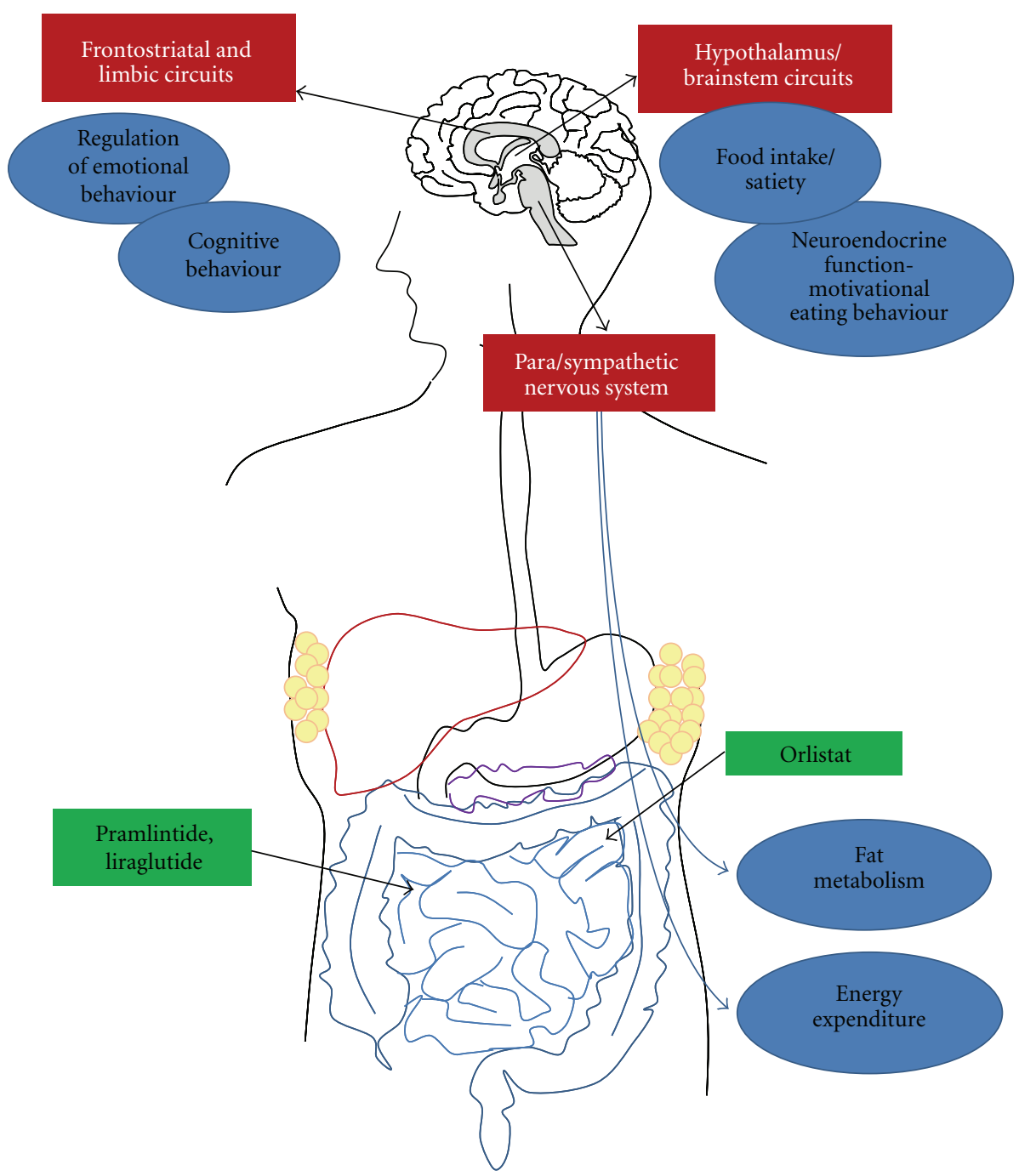

FIGURE 1: Overview of central and peripheral functions associated with anti-obesity pharmacotherapies.

total of 13 cases of severe liver injury ( 12 foreign reports with orlistat $120 \mathrm{mg}$ and a US report with the lower dose over-thecounter product [orlistat $60 \mathrm{mg}$ ]) and in May 2010 led to a label revision and the addition of a warning of severe liver injury.

3.5. Sibutramine. Sibutramine, a 5HT and NA uptake inhibitor, was originally developed as an antidepressant and subsequently found to reduce appetite [26]. It has 2 active metabolites, which inhibit NA and 5HT uptake (and to a lesser extent DA) without any direct effect on neuronal NA, DA and 5HT release. It has been suggested that sibutramine has a dual action to facilitate weight loss, an anorectic effect suggested to be mediated through the central $\alpha_{1}$ and $\beta_{1}$ adrenergic receptors and thermogenic effects through $\beta_{3}$ adrenergic receptors peripherally [73].

Maximal weight loss occurs by 6 months with sibutramine treatment $[74,75]$ and was dose related [74, 76, 77]. Sibutramine has consistently demonstrated significantly more weight loss than placebo in several RCTs with $\geq 1$ year of therapy $[1,74,75,78-80]$. Systematic reviews which included 7 sibutramine RCTs reported $4.3 \mathrm{~kg}$ (95\% CI: $3.6 \mathrm{~kg}$ to $4.9 \mathrm{~kg}$ ) or $4.6 \%$ (95\% CI: $3.8 \%$ to $5.4 \%$ ) greater weight loss than placebo $[58,70]$ (Table 3 ). There was $\geq 10 \%$ weight loss in $18 \%$ (95\% CI: $11 \%$ to $25 \%$ ) more sibutramine patients than placebo $[58,70]$. Attrition rates in sibutramine studies were approximately 30\%-40\% [58]. In RCTs of 3 to 12 months that compared sibutramine and orlistat, the weighted mean difference in weight loss was $2.2 \mathrm{~kg}$ (95\% CI 0.5-3.9) in favour of sibutramine [59]. A systematic review in adolescents which included 5 short-term studies has demonstrated significantly more weight loss with sibutramine than placebo, $5.3 \mathrm{~kg}$ ( $95 \% \mathrm{CI}, 3.5$ to $7.2 \mathrm{~kg})$ [71].

Although treatment with sibutramine has resulted in lowered concentrations of cholesterol and triglycerides, blood pressure and pulse rate may be increased [57]. Increases in diastolic blood pressure (DBP) with sibutramine were reported in 2 meta-analyses, one in hypertensive patients which included 2 studies where the weighted mean difference was $+3.2 \mathrm{~mm} \mathrm{Hg}(95 \% \mathrm{CI}+1.4$ to $+4.9 \mathrm{~mm} \mathrm{Hg})$ 
TABLE 3: Comparative efficacy of pharmacotherapy from recent meta-analyses of long-term studies in adults (12 months or more).

\begin{tabular}{|c|c|c|c|c|}
\hline Drug & No. of studies & Total subjects & $\begin{array}{l}\text { Mean weight difference } \\
(\mathrm{kg})(95 \% \mathrm{CI})\end{array}$ & Reference \\
\hline Rimonabant & 4 & $\begin{array}{c}\text { Placebo: } \sim 1600 \\
\text { Rimonabant: } \sim 2500\end{array}$ & $4.7(4.1,5.3)$ & {$[9,57,58]$} \\
\hline Orlistat & 14 & $\begin{array}{l}\text { Placebo: } 4509 \\
\text { Orlistat: } 4948\end{array}$ & $2.9(2.5,3.2)$ & {$[57,58]$} \\
\hline Sibutramine & 7 & $\begin{array}{c}\text { Placebo: } 699 \text { Sibutramine: } \\
837\end{array}$ & $4.2(3.6,4.8)$ & {$[57,58]$} \\
\hline $\begin{array}{l}\text { Sibutramine } \\
\text { Orlistat }\end{array}$ & 5 & $\begin{array}{l}\text { Sibutramine: } 229 \text { Orlistat: } \\
249\end{array}$ & $3.4(2.3,4.6)$ & {$[59]$} \\
\hline Bupropion* & 5 & $\begin{array}{c}\text { Bupropion: } 618 \\
\text { Placebo: } 344\end{array}$ & $2.8 \mathrm{~kg}(1.1$ to $4.5 \mathrm{~kg})$ & {$[56]$} \\
\hline
\end{tabular}

CI: confidence interval; $* 6$ to 12 month studies.

Note: another meta-analysis of 5 studies with rimonabant compared to placebo, did not provide mean weight difference in kg, however the odds ratio was $1.07(95 \%$ CI $0.9,1.3)[60]$.

[66], whilst another reported a placebo-controlled change in DBP of $+1.7(95 \%$ CI $0.7,2.6)$ and a small nonsignificant change in systolic BP $(+0.5 \mathrm{~mm} \mathrm{Hg}, 95 \% \mathrm{CI}-1.1,2.1)[81]$. Although sibutramine may reduce body weight by a similar amount as orlistat in hypertensive patients, it does not have the same beneficial effects on BP [65].

Weight loss was significantly greater at 1 year when sibutramine was combined with lifestyle modification $(10.8 \% \pm$ $10.2 \%$, mean $\pm \mathrm{SD}, P<.05)$ and $\operatorname{diet}(16.5 \% \pm 8.0 \%, P<$ $.05)$ than when sibutramine was used alone $(4.1 \% \pm 6.3 \%)$ [82]. Although the addition of orlistat to sibutramine therapy does not appear to enhance weight loss [83, 84], combination therapy with the amylin analogue pramlintide is producing promising results [85] (see Titled Drug Monotherapies and Combination Therapies under Investigation).

Apart from increases in $\mathrm{BP}$ and heart rate the most common side-effects reported with sibutramine are dry mouth, constipation, and headache $[57,66]$.

Following the report of two sibutramine-related deaths in Britain and serious side effects in France, the EMEA demanded a long-term trial in patients at high risk of cardiovascular disease hence the Sibutramine Cardiovascular Outcome trial (SCOUT) was initiated $[86,87]$. SCOUT is a double-blind, randomized, placebo-controlled outcome trial in 10,742 overweight or obese patients at high-risk for cardiovascular disease that commenced recruitment in December 2002. Of the total patients $97 \%$ had cardiovascular disease, $88 \%$ had hypertension, and $84 \%$ had type 2 diabetes [88]. Until recently the only published results from SCOUT were from the 4-6-week lead in period [13-15, 87, 89]. At 6 weeks there was a significant reduction in body weight $(2.2 \mathrm{~kg})$, waist circumference $(2.0 \mathrm{~cm})$, systolic $(3.0 \mathrm{~mm} \mathrm{Hg})$ and diastolic blood pressure $(1.0 \mathrm{~mm} \mathrm{Hg})$ with sibutramine treatment, however pulse rate was increased by $1.5 \mathrm{bpm}$ (all $P<.001$ ) [89]. Results were similar for the diabetic patients in the study, that is, a $2.1 \mathrm{~kg}$ decrease in weight and decrease in blood pressure by $3.5 / 1.0 \mathrm{~mm} \mathrm{Hg}$ with sibutramine compared to placebo [14]. A total of 9,800 patients were followed up for six years. The preliminary data released in late 2009, suggested that sibutramine was associated with a higher rate of $\mathrm{CV}$ events than placebo [90], whilst data from a FDA early communication indicated that there was an increased rate of CV events (heart attacks, strokes, resuscitated cardiac arrest, CV death) in patients with cardiovascular disease and diabetes (11.9\% placebo, $13.9 \%$ sibutramine, hazard ratio $1.18,95 \%$ CI $1.02-1.35$, $P=.023)$ [91]. The EMEA concluded that the benefits of sibutramine did not outweigh the risks and recommended that all marketing authorisations for medicines containing sibutramine should be suspended throughout Europe [10]. The FDA initially allowed sibutramine to be available, but asked for stronger warnings on the product labels [92]. The warning recommended that sibutramine should not be used by people who have a history of stroke or heart attacks and uncontrolled high blood pressure. The recent publication of the SCOUT study which had a mean follow-up period of 3.4 years reported a large number of patients that discontinued treatment ( $40.2 \%$ sibutramine, $42.3 \%$ placebo), a higher risk of cardiovascular outcome with sibutramine $(11.4 \%$ versus $10 \%$, hazard ratio $1.1695 \%$ CI $1.03-1.31, P=.02$ ). [17] In particular there was a higher rate of nonfatal MI and nonfatal stroke for sibutramine $(4.1 \%$ and $2.6 \%$, resp.) than placebo (3.2\% and $1.9 \%)$.

A 3-year prospective observational study of 15,686 patients prescribed sibutramine in New Zealand has not demonstrated a higher risk of death from a cardiovascular event [93]. The FDA is currently reviewing the potential benefits and risks of sibutramine [94].

3.6. Rimonabant. Rimonabant, an endocannabinoid receptor (subtype 1) blocker, was developed as a result of observations on the appetite stimulation associated with recreational cannabis use (Table 2). The drug has a range of both central and metabolic peripheral effects and had also been investigated for smoking cessation $[26,95]$.

Attrition rates in a pooled study of 5,580 patients without diabetes and 1,047 patients with diabetes taking rimonabant $20 \mathrm{mg}$ daily for one year and a hypocaloric diet were approximately $40 \%$ [96]. In the nondiabetic patient subgroup, rimonabant reduced body weight by $6.5 \mathrm{~kg}$ compared to 
placebo $(P<.001)$. Weight-loss of $\geq 5 \%$ was achieved in $50.8 \%$ of the treatment group, and waist circumference was reduced by $6.4 \mathrm{~cm}$ compared to placebo $(P<.001)$ (Table 4$)$ [96]. There was an improvement in glycaemic control in diabetic patients with a reduction in mean $\mathrm{HbA1C}$ levels of 0.6\% $(P<.001)$ [96]. Discontinuation due to side-effects occurred in $13.8 \%$ of rimonabant patients and in $7.2 \%$ of placebo patients. The most commonly experienced adverse events were gastrointestinal disorders, mood alterations with depressive symptoms, anxiety, dizziness, nausea, and upper respiratory tract infections.

Four large Rimonabant in Obesity and Related Metabolic Disorders (RIO) Phase III studies (RIO-Europe, RIO-North America, RIO-Diabetes, RIO-Lipids) were included in two meta-analyses and a systematic review to investigate the efficacy and safety of rimonabant in improving cardiovascular and metabolic risk factors in overweight patients [9, 60] (Table 3). Compared with placebo, rimonabant $(20 \mathrm{mg})$ produced a $4.9 \mathrm{~kg}(95 \% \mathrm{CI} 4.3,5.0)$ greater reduction in body weight as well as improvements in waist circumference $(-3.84 \mathrm{~cm}, 95 \% \mathrm{CI}-4.26,-3.42)$, high-density lipoprotein cholesterol, triglyceride levels, and systolic and diastolic BP [60]. A subsequent meta-analysis which included the 4 RIO studies provided evidence of the likelihood of experiencing serious side effects with rimonabant [9]. The odds ratio (OR) for depression was 2.51 (95\% CI, 1.23-5.12) and 3.03 $(95 \%, 1.09-8.42)$ for anxiety [9]. A systematic review and meta-analysis reported that the $20 \mathrm{mg}$ rimonabant dose was associated with an increased risk of adverse events (RR 1.35; 95\% CI 1.17-1.56), increased discontinuation rate (RR 1.79; 95\% CI 1.35-2.38), and psychiatric (RR 2.35; 95\% CI 1.663.34), and nervous system adverse events (RR 2.35; 95\% CI 1.49-3.70) [100]. The number needed to harm (NNH) for psychiatric adverse events was 30 [100]. In a comparison with other pharmacotherapies the risk ratios for discontinuation in RCTs due to adverse events were significantly elevated for rimonabant (2.00; 95\% CI 1.66-2.41) and orlistat (1.59; 95\% CI $1.21-2.08)$, but not sibutramine (0.98, 95\% CI $0.68-$ 1.41) [20]. The risk difference was largest for rimonabant (7\%, 95\% CI: 5\%-9\%; NNH 14, 95\% CI: 11-19) compared with placebo, followed by orlistat $(3 \%, 1 \%-4 \%$; NNH 39, 95\% CI: 25-83), while no significant difference was seen for sibutramine $(0.2 \%, 95 \% \mathrm{CI}:-3 \%$ to $4 \%$; NNH 500$)$.

In late 2008, the manufacturers of rimonabant announced that all clinical research studies would be stopped permanently. This announcement followed a decision by the EMEA to withdraw marketing of the drug as the risks especially of psychiatric side effects were considered to outweigh the drug's benefits [101].

\subsection{Systematic Reviews Comparing Several Drug Therapies.} Several meta-analyses and systematic reviews have demonstrated that pharmacotherapy in combination with a low calorie diet and in some cases exercise generally results in a maximum weight reduction at six months of $1-9.6 \mathrm{~kg}$, maintenance of weight loss with continued therapy, and a regain in weight after drug therapy is discontinued [7, 30]. The largest mean effect sizes were demonstrated with amphetamines, fenfluramines and sibutramine, though no drug demonstrated clear superiority $[30,58]$ and most of the drugs have been prescribed for a limited duration. A systematic review which included 14 RCTs with orlistat, 7 RCTs of sibutramine and 4 RCTs with rimonabant compared to placebo, reported $2.9 \mathrm{~kg}$ greater weight loss with orlistat than placebo, $4.2 \mathrm{~kg}$ for sibutramine and $4.7 \mathrm{~kg}$ for rimonabant (Table 3). Patients on active drug therapy were significantly more likely to achieve $\geq 5 \%$ and $\geq 10 \%$ weight loss [57]. Continuation on treatment was a problem with attrition rates averaging 30\%-40\% within 12 months [57].

In adolescents a meta-analyses of RCTs with orlistat and sibutramine demonstrated a mean decrease in weight between the intervention and control groups of $5.25 \mathrm{~kg}(95 \%$ CI: 3.03-7.48) after a minimum follow-up of 6 months [71]. Systemic reviews of pharmacotherapy for overweight and obese children, adolescents, and older adults only include a limited number of mainly short-term studies [21, 102-104] hence, there is a lack of high-quality evidence to support the efficacy and safety of drug therapy in these populations.

\section{Drug Monotherapies and Combination Therapies under Investigation}

Some already marketed drugs (that are approved for other indications) and several new agents are currently being evaluated for the management of obesity $[25,105,106]$. These include tesofensine, a pharmacological agent that targets the inhibition of NA, DA, and 5HT reuptake and, liraglutide a glucagon-like peptide-1 analog and lorcaserin the selective serotonin 2C (5-HT2C) receptor agonist (Table 2$)$. There are also several combination drug therapies in Phase III trials including bupropion and naltrexone, bupropion and zonisamide, phentermine and topiramate, and pramlintide and metreleptin. Some drugs that were in late phase trials such as axokine, a naturally occurring re-engineered human protein known as cilary neurotrophic factor, taranabant a CB1R inverse agonist, and ecopipam a selective dopamine D1/D5 antagonist have been abandoned, the latter two due to an increase in psychiatric adverse events. There are also some weight loss medications that have previously been used in the management of diabetes that are being evaluated for weight loss, that is, pramlintide, liraglutide, and exenatide.

4.1. Pramlintide. Pramlintide, a synthetic analog of the pancreatic hormone amylin, was originally used for the treatment of type 1 and 2 diabetes. It has been associated with reduced, appetite, food intake and enhanced satiety through delayed gastrointestinal motility and is currently under investigation as a potential treatment for obesity [25, 105]. In a 16-week dose escalation RCT 3.7\% mean weight loss was demonstrated with pramlintide $240 \mu \mathrm{g}$ given as a subcutaneous (SC) injection compared to placebo $(P<$ .001 ) and $\geq 5 \%$ weight loss was achieved in $31 \%$ of patients $(P<.001)$ [107]. In obese patients participating in a 4 month RCT of pramlintide at doses of 120, 240, and $360 \mu \mathrm{g}$ administered two or three times a day, followed by a single blind extension to 1 year, weight loss was regained in the placebo group but maintained or continued in all but the 


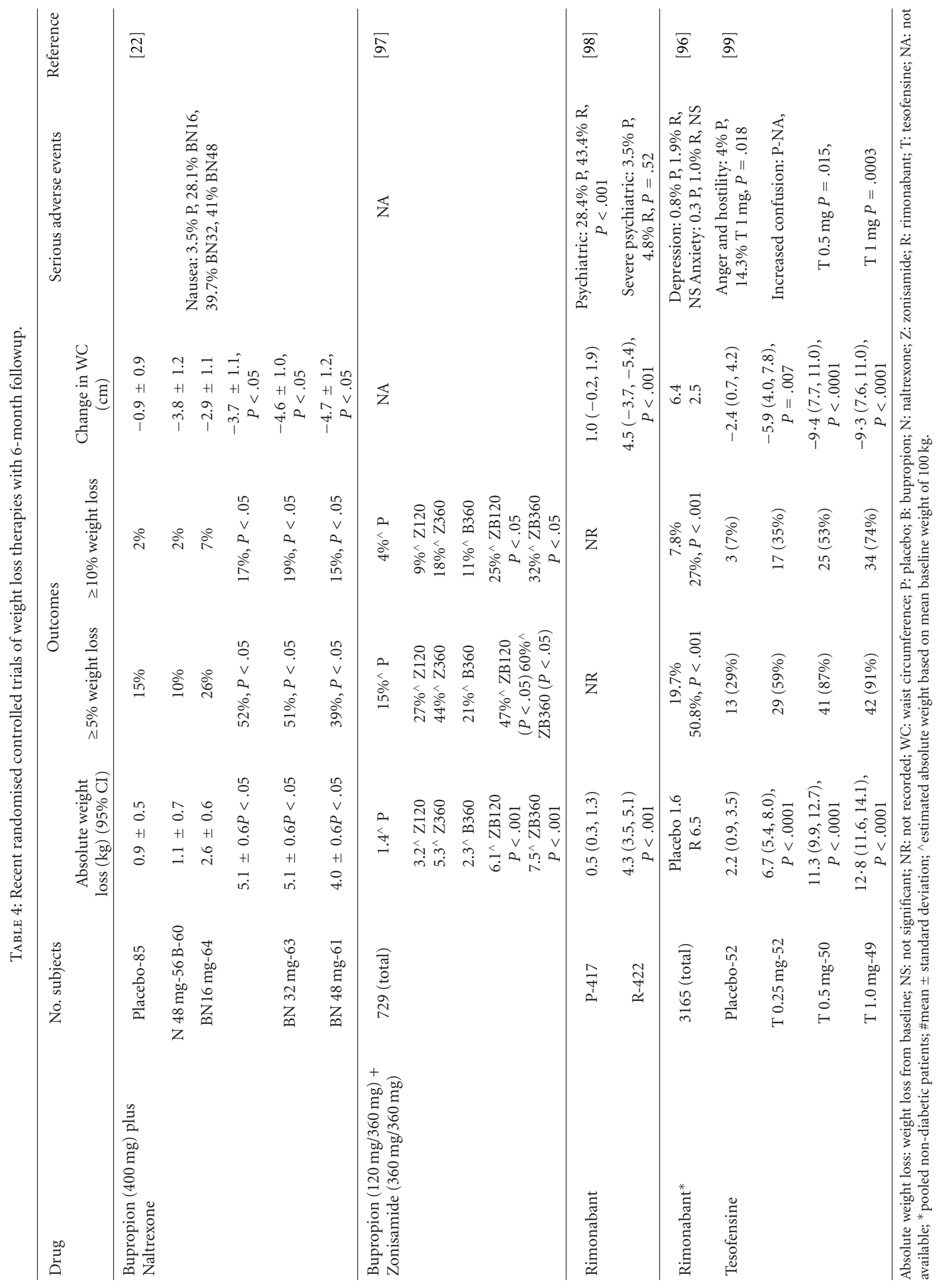


pramlintide $120 \mu \mathrm{g}$ twice daily arm [108]. Nausea was the most common adverse event.

4.2. Glucagon-Like Peptide-1 (GLP1) Analogues: Liraglutide, Exenatide. Liraglutide and exenatide are glucagon-like peptide-1 (GLP1) analogues developed and approved for the treatment of type 2 diabetes (Table 2) [109]. Phase III trials of liraglutide have demonstrated beneficial weight loss in obese patients. These analogues have a dual mechanism of action, that is, on the gastrointestinal (GI) tract and the brain. Signals from the GI tract are sent to the brain to increase the secretion of leptin, resulting in suppressed appetite, energy intake and a delay in gastric emptying. A key benefit with long-term use of liraglutide and exenatide is a decrease in HbA1c levels and systolic BP [110, 111]. A recent 20 week dose-ranging RCT of liraglutide $(1.2,1.8 \mathrm{mg}, 2.4 \mathrm{mg}$, $3.0 \mathrm{mg})$ in comparison with orlistat $(120 \mathrm{mg})$ treatment in 564 nondiabetic obese patients demonstrated a mean weight loss of $4-8 \mathrm{~kg}, 5.5 \mathrm{~kg}, 6.3 \mathrm{~kg}$, and $7.2 \mathrm{~kg}$, resp. compared with $2.8 \mathrm{~kg}$ with placebo and $4.1 \mathrm{~kg}$ with orlistat $(P=.003$ for $1.2 \mathrm{mg}, P<.0001$ for $1.8-3.0 \mathrm{mg}$ liraglutide) [112]. Higher doses of liraglutide $(2.4$ and $3.0 \mathrm{mg}$ ) demonstrated significantly greater mean weight loss than orlistat. The most common adverse events with liraglutide were nausea and vomiting, but these were not significantly different to the placebo group. Patients treated with liraglutide also showed a significant reduction in blood pressure and the prevalence of prediabetes $(84 \%-96 \%)$.

Exenatide is currently only in Phase II trials [113] for obesity but early results from an open-label study have demonstrated weight loss as well as an improvement in glycemic control [114].

4.3. Taranabant. Taranabant a cannabinoid CB-1 receptor (CB1R) inverse agonist which reduces appetite and increases energy expenditure has been evaluated for the treatment of obesity [115]. It demonstrated greater weight loss with higher doses in a 12 week RCT that assessed its safety and efficacy. Four Phase III trials have been published, two assessed the risk/benefit profile of low and high doses and one included patients with type 2 diabetes [23, 116-118]. Mean weight loss after 1 year of taranabant was $5.0 \mathrm{~kg}$ with the $0.5 \mathrm{mg}$ dose, $5.2 \mathrm{~kg}$ with the $1 \mathrm{mg}, 6.4 \mathrm{~kg}$ with the $2 \mathrm{mg}$ compared to $1.4 \mathrm{~kg}$ for placebo (all $P<.001$ ) [118] Significantly more patients achieved $\geq 5 \%$ and $\geq 10 \%$ loss of baseline body weight with taranabant than placebo $(P<.001$ for all doses) (Table 5). Approximately $80 \%$ of patients from each taranabant dose group experienced one or more adverse events [118].

A study using higher doses $(2 \mathrm{mg}, 4 \mathrm{mg}$, and $6 \mathrm{mg}$ ) achieved greater mean weight loss at 1 year of treatment which persisted to 2 years (Table 5) [23]. Although weight loss with the highest dose of $6 \mathrm{mg}$ proved to be the most efficacious after 1 year of treatment, the adverse events were significantly increased with increasing doses particularly serious psychiatric events which included depression, depressive mood, anxiety, anger, and aggression [23]. The odds ratios for suicidality with increasing doses of taranabant after 1 year treatment were 1.74 (95\% CI 0.87-3.51) with the $2 \mathrm{mg}$ dose,
2.16 (95\% CI 1.10-4.25) for $4 \mathrm{mg}$, and 2.34 (95\% CI 1.11$4.96)$ with the $6 \mathrm{mg}$. Hence, only the lower doses $(2 \mathrm{mg}$ and $4 \mathrm{mg}$ ) were used for the remainder of the study.

The overall safety and efficacy profile of taranabant from the Phase III trials did not support its further development in the treatment of obesity, and clinical trials were ceased [23, $117,119]$.

4.4. Lorcaserin. Lorcaserin is a selective serotonin $2 \mathrm{C}$ receptor agonist (5-HT2C), sharing characteristics similar to fenfluramines, which acts through another serotonin receptor (5-HT2B) that has been associated with cardiac valvular disease [124] (Table 2).

Recent clinical trials with lorcaserin have demonstrated effective weight loss compared to placebo along with a good safety profile $[125,126]$. Results from two recently presented pivotal Phase III trials, BLOOM (Behavioral modification and Lorcaserin for Overweight and Obesity Management) and BLOSSOM (Behavioral modification and Lorcaserin Second Study for Obesity Management) indicated greater weight loss with lorcaserin than with placebo (Table 5) [120, $127,128]$. In these RCTs, 6380 non-diabetic patients aged 1866 years with a BMI $27-45 \mathrm{~kg} / \mathrm{m}^{2}$ were treated for 52 weeks with lorcaserin $10 \mathrm{mg}$ twice daily or with placebo. Using the pooled data from these two trials, weight loss at 52 weeks decreased by $5.8 \%$ in the lorcaserin group and $2.5 \%$ in the placebo group $(P<.0001)$ [127]. Weight loss was similar amongst males and females but was higher in Caucasian patients than African American patients or Hispanic patients and patients $>50$ years lost more weight than younger patients. Average weight loss at 1 year in the BLOOM study was $5.8 \pm 0.2 \mathrm{~kg}$ with lorcaserin and $2.2 \pm 0.1 \mathrm{~kg}$ with placebo ones $(P<.001)$ with $47.5 \%$ and $20.3 \%$ loosing $\geq 5 \%$ of their body weight (Table 5) [120]. Weight loss was maintained in $67.9 \%$ of lorcaserin patients in year 2 and $50.3 \%$ of placebo $(P<.001)$ (Table 6) [120]. After 52 weeks of lorcaserin treatment, changes in lipid and glucose values were more favourable in responders than nonresponders, and twice as many patients responded to lorcaserin as placebo (i.e., $\geq 5 \%$ body weight loss in $47.1 \%$ lorcaserin patients and $22.6 \%$ placebo) [128]. The most frequent adverse events reported were headache, dizziness and nausea, but these were not significantly different between treatment groups (Table 5). There was no increase in the rate of cardiac valvulopathy after 2-year treatment with lorcaserin [120].

Although the recently published study indicated lorcaserin was safe and moderately effective, there was a high dropout rate [120]. Lorcaserin was submitted for FDA approval however in September 2010 the advisors recommended against approval as they did not consider that the potential benefits of the drug outweighed the risks. In particular they claimed that patients on lorcaserin did not achieve the percentage point criterion set by the FDA. The FDA which usually takes the advice of its committees is expected to decide in October whether to approve lorcaserin.

4.5. Tesofensine. Tesofensine is another novel pharmacological agent which inhibits the uptake of presynaptic NA, DA, and 5HT (Table 2, Figure 1). Tesofensine was discovered 


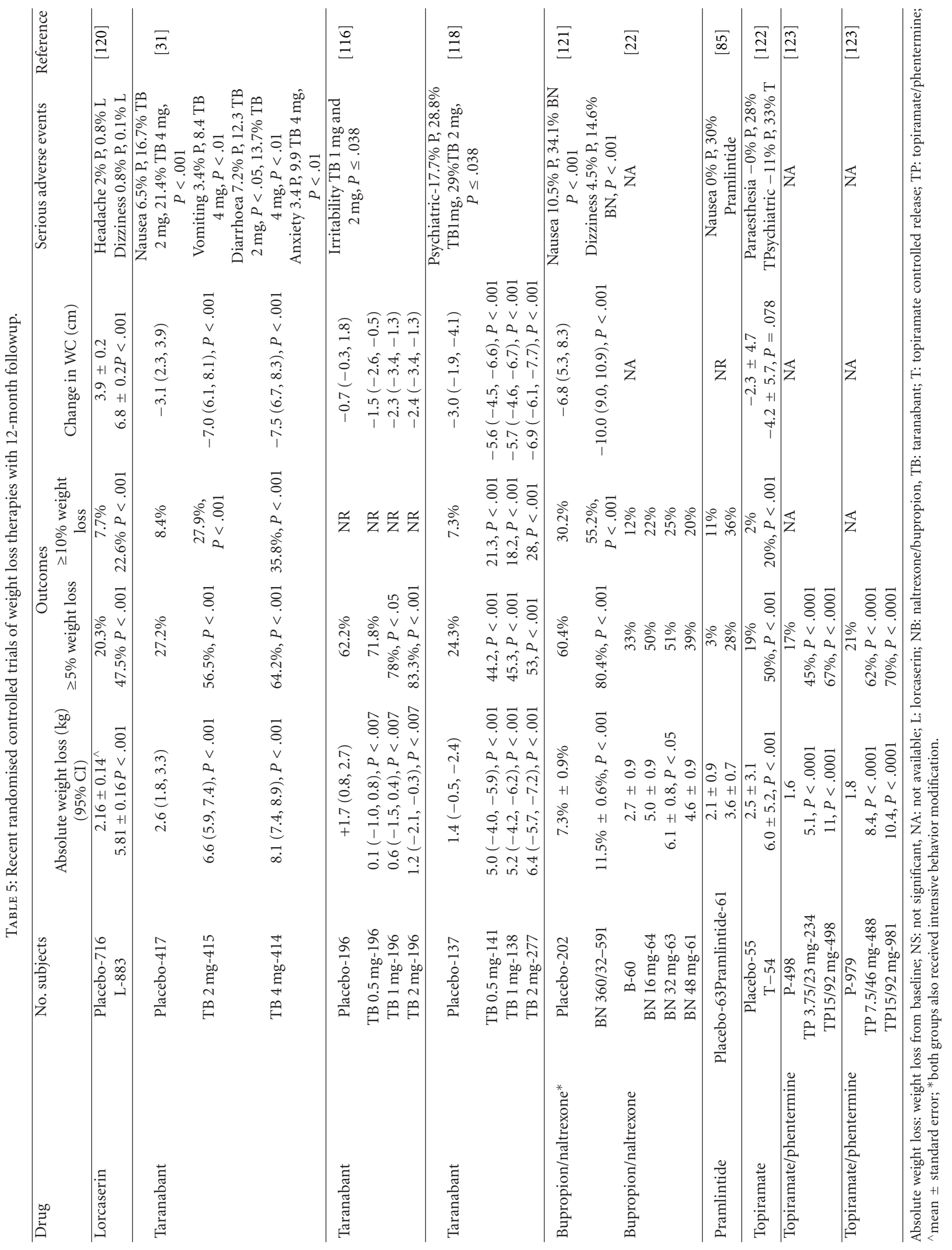


TABLE 6: Recent randomised controlled trials of weight loss therapies with 2-years followup.

\begin{tabular}{|c|c|c|c|c|c|c|c|}
\hline \multirow[t]{2}{*}{ Drug } & \multirow[t]{2}{*}{ No subjects } & \multicolumn{4}{|c|}{ Outcomes } & \multirow{2}{*}{$\begin{array}{c}\text { Serious } \\
\text { adverse events }\end{array}$} & \multirow[t]{2}{*}{ Reference } \\
\hline & & $\begin{array}{l}\text { Absolute weight loss } \\
\quad(\mathrm{kg})(95 \% \mathrm{CI})\end{array}$ & $\geq 5 \%$ weight loss & $\geq 10 \%$ weight loss & $\begin{array}{l}\text { Change in WC } \\
(\mathrm{cm})\end{array}$ & & \\
\hline \multirow[t]{3}{*}{ Lorcaserin } & P-684 & $3.0 \% \pm 0.2 \%$ & $50.3 \%$ & $7.7 \%$ & $4.3 \pm 0.2$ & NS & {$[120]$} \\
\hline & L-564 & $7.0 \% \pm 0.2 \%$ & $67.9 \%$ & $22.6 \%$ & $8.1 \pm 0.2$ & & \\
\hline & & $P<.001$ & $P<.001$ & $P<.001$ & $P<.001$ & & \\
\hline \multirow[t]{3}{*}{ Taranabant } & P-244 & $1.4(0.3,2.5)$ & $30.3 \%$ & 13.4 & $-2.7(1.5,3.8)$ & NS & {$[23]$} \\
\hline & TB 2 mg-264 & $\begin{array}{c}6.4(5.3,7.4) \\
P<.001\end{array}$ & 59.6, $P<.001$ & $33, P<.001$ & $\begin{array}{c}-6.3(5.2,7.4) \\
P<.05\end{array}$ & & \\
\hline & TB 4 mg-260 & $\begin{array}{c}7.6(6.5,8.7) \\
P<.001\end{array}$ & $64.8, P<.001$ & $37.9, P<.001$ & $\begin{array}{c}-7.0(5.9,8.1), \\
P<.01\end{array}$ & & \\
\hline
\end{tabular}

Absolute weight loss = weight loss from baseline; WC: waist circumference, NR: not recorded, TB: taranabant, NS: not significant; P: placebo; L: lorcaserin.

to decrease weight in patients receiving the drug for the treatment of Alzheimer's and Parkinson's disease [129]. Investigators performed a dose-dependent analysis in obese patients for 14 weeks, demonstrating a mean change in weight loss for tesofensine doses of $0.125 \mathrm{mg}, 0.25 \mathrm{mg}, 0.5 \mathrm{mg}$ and $1 \mathrm{mg}$ of $2.1 \%, 8.2 \%, 14.1 \%$, and $20.9 \%$, resp. [129]. Of the total obese patients in the study, $32.1 \%$ achieved a $\geq 5 \%$ weight loss with tesofensine, $(P<.001$ for $0.25,0.5$, and $1.0 \mathrm{mg}$ versus placebo). No effect on blood pressure was observed, but there were increases in heart rate with increasing dose.

Further evidence was demonstrated in another 24-week Phase IIb randomised dose-dependent tesofensine trial in 203 obese individuals, with $79 \%$ of participants completing the study [99]. Weight loss was dose dependant with $4.5 \%$ weight loss $(0.25 \mathrm{mg}), 9.2 \%(0.5 \mathrm{mg})$, and $10.6 \%(1.0 \mathrm{mg})$ and was greater than that achieved with diet and placebo $(P<.0001)$ (Table 4$)$. The drug was well tolerated with no significant increases in systolic or diastolic blood pressure however, heart rate was increased by 7.4 beats/min in the middose group $(P=.0001)$.

4.6. Naltrexone. Naltrexone, a high affinity and long-acting opioid receptor antagonist which was originally produced for the treatment of opioid and alcohol dependence, decreased food intake and led to weight loss in former narcotic addicts. The role of opioid receptors in eating behaviour was initially demonstrated following the administration of naloxone to rats resulting in a significant reduction in short-term food intake by blocking $\beta$-endorphin (Table 2) [130]. In RCTs naltrexone (an analogue of naloxone) has not consistently demonstrated statistically significant weight loss in obese and lean subjects [131-134].

4.7. Bupropion Plus Naltrexone (Contrave). Bupropion was combined with the naltrexone following the recognition that naltrexone blocks $\beta$-endorphin mediated proopiomelanocortin (POMC) autoinhibition to sustain $\alpha$ MSH release, whilst bupropion (through DA receptors) activates POMC neurons and enhances the release of the anorexiant neuropeptide $\alpha$-MSH in the hypothalamus [22,
135, 136]. The bupropion-naltrexone combination is said to tackle the motivation/reinforcement that food brings (DA effect) and the pleasure/palatability of eating (opioid effect) [137].

A 24 week dose ranging study of naltrexone/bupropionSR did not demonstrate increased weight loss with increasing doses of naltrexone (weight loss for $16 \mathrm{mg}$ dose was $4.62 \%$ [95\% CI: -6.24 to $-2.99, P<.001$ ], for $32 \mathrm{mg}$ dose $4.65 \%$ [95\% CI: -6.20 to $-3.09, P<.001$ ], and for the $48 \mathrm{mg}$ dose $3.53 \%$ [95\% CI: -5.15 to $-1.90, P<.001]$ ) (Table 4 ) [22]. Nevertheless, weight-loss was maintained in a 24 -week extended period.

An open-label 24-week study demonstrated that naltrexone $32 \mathrm{mg}$ SR/bupropion-SR $360 \mathrm{mg}$ resulted in significant improvements in depressive symptoms in addition to weight loss and improved control of eating in overweight and obese women with major depression [138]. Depression scores as measured with the Montgomery-Asberg Depression Rating Scale decreased from an average of 23.7 at baseline to 10.5 (consistent with mild depression) at week $12(P<.001)$ and 8.4 (consistent with remission) at week $24(P<.001)$.

Several Phase III trials have been conducted in both diabetic and non-diabetic patients including COR-I, COR-II, COR-BMOD and COR-Diabetes [105, 121, 139-141]. CORDiabetes was a 56-week RCT of 505 overweight or obese patients with type 2 diabetes ( $\mathrm{Hb}$ A1C levels $7 \%$ to $10 \%$, mean $8.0 \%$ ) randomized to naltrexone $32 \mathrm{mg}$ SR/bupropion $360 \mathrm{mg}$ SR or placebo [140]. The naltrexone/bupropion patients lost significantly more weight $(5.0 \%$ versus $1.8 \%$, $P<.001)$ at 56 weeks [140] with $44.5 \%$ of patients achieving $\geq 5 \%$ loss of body weight compared to $18.9 \%$ on placebo. Greater improvement in glycemic control was achieved in the treatment group with average baseline $\mathrm{HbA1C}$ reduced by $0.6 \%$ compared to $0.1 \%$ for placebo. The investigators noted that over $44 \%$ of treated patients achieved the American Diabetes Association treatment target of $<7 \%$ for $\mathrm{HbAlC}$ compared to $26 \%$ of placebo patients $(P<.001)$.

This drug combination has generally been welltolerated in most patients (Table 5). Nausea was the most frequent adverse event, and this occurred more frequently with higher naltrexone doses. A new drug application has been submitted 
for review by the FDA with the outcome expected in December 2010.

4.8. Bupropion Plus Zonisamide. The combination of bupropion with the epilepsy agent, zonisamide has been evaluated in three Phase II trials [97, 142-144]. The mechanism of action for zonisamide has not been fully characterised, however it has demonstrated biphasic DA and 5HT activity $[142,145]$. The potential of zonisamide in the management of obesity was demonstrated in a small RCT where zonisamide patients experienced significantly more weight lost than those on placebo [145]. A 24-week RCT of bupropion $300 \mathrm{mg}$ combined with zonisamide $400 \mathrm{mg}$ achieved greater weight loss (9.2\%) than either drugs alone (bupropion 6.6\%, zonisamide $3.6 \%$ ) or placebo (0.4\%) [143]. Similar results were observed in a randomised open-label study [142]. Weight loss in a 24 week multicentre RCT with either drug alone and different combinations of zonisamide SR with bupropion SR were $1.4 \%$ with placebo, $3.2 \%$ with zonisamide SR $120 \mathrm{mg}$, 5.3\% with zonisamide SR $360 \mathrm{mg}$, $2.3 \%$ with bupropion SR $360 \mathrm{mg}, 6.1 \%$ with zonisamide SR $120 \mathrm{mg} /$ bupropion SR $360 \mathrm{mg}$, and $7.5 \%$ for zonisamide SR $360 \mathrm{mg} /$ bupropion SR $360 \mathrm{mg}$ with $\geq 5 \%$ weight loss in $15 \%$, $27 \%, 44 \%, 21 \%, 47 \%, 60 \%$, respectively, [97]. The most frequent adverse events reported were headache, nausea and insomnia.

Weight loss with zonisamide and bupropion appears to be greater than that observed with the bupropion/naltrexone combination over the same period of treatment [22].

4.9. Topiramate Plus Phentermine (Qnexa). Topiramate is a GABA agonist and an approved antiepileptic drug which has been trialed as monotherapy for weight loss [1]. It acts as an appetite suppressant that has been suggested to influence kainate/ $\alpha$-amino-3-hydroxy-5-methylisoxozole4-propionicacid glutamate receptors, voltage-gated sodium channels, and $\gamma$-aminobutyric acid-A activity [146], however the exact mechanism of action for weight loss is not known (Table 2). Several RCTs demonstrated greater weight loss with topiramate monotherapy than placebo with continued weight loss throughout the duration of the study [1]. However concerns regarding central and peripheral nervous system adverse effects led to Phase III trials of topiramate being halted and topiramate being reformulated. As the sustained release formulation did not have better tolerability trials were discontinued in December 2004.

The combination of controlled release low dose topiramate with low dose phentermine has recently been shown to be effective for weight loss treatment [147]. A 28week RCT using phentermine with topiramate $(92 \mathrm{mg} / 15 \mathrm{mg}$ and $46 \mathrm{mg} / 7.5 \mathrm{mg}$ doses) demonstrated a $9.2 \%$ weight loss compared to a $6.4 \%$ weight loss with topiramate alone, $6.1 \%$ for phentermine alone and $1.7 \%$ for placebo [123]. The tolerance and safety of this drug combination are being evaluated in several Phase III trials (EQUATE, EQUIP, CONQUER). In July 2010 an FDA advisory committee agreed that the phentermine/topiramate combination was effective in reducing weight loss however it refused to endorse a recommendation for the treatment of obesity due to safety concerns which included increased heart rate, possible birth defects, and psychiatric problems (depression, suicidal thoughts, impaired memory and concentration) [148]. The final FDA determination on the drug combination is expected in late October 2010.

4.10. Pramlintide Combination Therapies. Pramlintide has been combined with recombinant methyl human leptin (metreleptin), an adipocyte-derived hormone involved in long-term signalling of adiposity and energy intake [149]. In early trials this combination of an amylin and a leptin agonist has demonstrated greater weight loss than either drug alone $[148,149]$. Weight loss with pramlintide/metreleptin was $12.7 \% \pm 0.9 \%$ (mean $\pm \mathrm{SE}$ ) to week 20 compared with $8.4 \% \pm 0.9 \%$ for pramlintide $(P<.001)$ and $8.2 \% \pm$ $1.3 \%$ for metreleptin $(P<.01)$ [149]. Pramlintide is also being evaluated in combination with sibutramine and phentermine [85]. In a 24-week open-label study weight loss was in subjects taking pramlintide and sibutramine was $11.1 \% \pm 1.1 \%$ (mean $\pm \mathrm{SE}$ ), $11.3 \% \pm 0.9 \%$ for those taking pramlintide plus phentermine, $3.7 \% \pm 0.7 \%$ with pramlintide alone, and $2.2 \% \pm 0.7 \%$ with placebo $(P<.001)$ [85]. Common side effects experienced with combination treatments were nausea and increased heart rate [85]. There was a significant increase in heart rate and blood pressure with the combination of pramlintide and sibutramine (3.1 \pm 1.2 beats $/ \mathrm{min}, P<.05 ; 2.7 \pm 0.9 \mathrm{~mm} \mathrm{Hg}, P<.01)$ and pramlintide with phentermine $(4.5 \pm 1.3$ beats $/ \mathrm{min}, P<$ $.01 ; 3.5 \pm 1.2 \mathrm{~mm} \mathrm{Hg}, P<.001$ ). Pramlintide is also being investigated with exenatide, the GLP-1 agonist used for the treatment of obesity in diabetic and non-diabetic patients [113].

\section{Conclusion}

Pharmacological interventions in addition to lifestyle changes (diet and physical activity) and in some cases behavioural modifications are used to promote weight loss. At present, only two drugs are currently approved and available for the long-term treatment of obesity-orlistat and sibutramine. However, there are several drugs and combination drug therapies undergoing Phase III trials that may be approved in the next few years. Pharmacotherapies have demonstrated a significant though modest decrease in weight compared to placebo over 1-2 years. Unfortunately weight loss following pharmacological intervention is not sustained when therapy is discontinued with individuals regaining some or all of the weight that was originally lost.

Obesity is often considered a chronic disease, hence it requires long-term therapy. Currently, there is a lack of high quality evidence from long-term studies of both the efficacy and safety of pharmacological interventions for obesity. Serious safety concerns have resulted in the withdrawal of some drugs that had originally received market approval whilst other drugs have been abandoned during Phase III evaluation. An increase in psychiatric disorders following Phase III studies (RIO-Europe, RIO-North America, RIO-Diabetes and RIO-Lipids) with rimonabant treatment resulted in its withdrawal from the European market two 
years after its approval. Orlistat treatment is associated with troublesome side effects such as diarrhoea, flatulence, bloating, abdominal pain, and dyspepsia which may not be acceptable to some patients on long-term treatment whilst the recent concerns of severe liver disease have led to a review of its safety. Long-term treatment with sibutramine is associated with a positive though modest efficacy profile and a low risk profile for neuropsychiatric adverse events; however we will need to wait for the publication of the full results of the SCOUT study to determine if there is an increase rate of $\mathrm{CV}$ events in patients with cardiovascular disease and diabetes.

Among the drugs in late phase trials, lorcaserin appears to be a potential candidate for long-term treatment in obesity due to its demonstrated efficacy and tolerable safety profile. Treatment with topiramate and taranabant result in significant weight loss in long-term studies, however both of these drugs have serious adverse effects. In the case of taranabant the psychiatric adverse events have led to the discontinuation of Phase III trials. Amongst the combination therapies both bupropion with naltrexone and bupropion with zonisamide have demonstrated effective weight loss and appear to be generally well tolerated based on published results from RCTs whereas there appears to be concerns regarding the safety of combination therapy using topiramate with phentermine.

\section{References}

[1] L. L. Ioannides-Demos, J. Proietto, and J. J. McNeil, "Pharmacotherapy for obesity," Drugs, vol. 65, no. 10, pp. 13911418, 2005.

[2] L. Abenhaim, Y. Moride, F. Brenot et al., "Appetitesuppressant drugs and the risk of primary pulmonary hypertension," The New England Journal of Medicine, vol. 335, no. 9, pp. 609-616, 1996.

[3] L. L. Ioannides-Demos, J. Proietto, A. M. Tonkin, and J. J. McNeil, "Safety of drug therapies used for weight loss and treatment of obesity," Drug Safety, vol. 29, no. 4, pp. 277-302, 2006.

[4] H. Jick, C. Vasilakis, L. A. Weinrauch, C. R. Meier, S. S. Jick, and L. E. Derby, "A population-based study of appetite-suppressant drugs and the risk of cardiac-valve regurgitation," The New England Journal of Medicine, vol. 339, no. 11, pp. 719-724, 1998.

[5] Y. K. Loke, S. Derry, and A. Pritchard-Copley, "Appetite suppressants and valvular heart disease-a systematic review," BMC Clinical Pharmacology, vol. 2, article 6, 2002.

[6] M. Sachdev, W. C. Miller, T. Ryan, and J. G. Jollis, "Effect of fenfluramine-derivative diet pills on cardiac valves: a metaanalysis of observational studies," American Heart Journal, vol. 144, no. 6, pp. 1065-1073, 2002.

[7] G. Glazer, "Long-term pharmacotherapy of obesity 2000: a review of efficacy and safety," Archives of Internal Medicine, vol. 161, no. 15, pp. 1814-1824, 2001.

[8] W. N. Kernan, C. M. Viscoli, L. M. Brass et al., "Phenylpropanolamine and the risk of hemorrhagic stroke," The New England Journal of Medicine, vol. 343, no. 25, pp. 1826-1832, 2000.

[9] R. Christensen, P. K. Kristensen, E. M. Bartels, H. Bliddal, and A. Astrup, "Efficacy and safety of the weight-loss drug rimonabant: a meta-analysis of randomised trials," The Lancet, vol. 370, no. 9600, pp. 1706-1713, 2007.
[10] European Medicines Agency. Withdrawal of the marketing authorisation in the European Union, 2009, http://www .emea.europa.eu/humandocs/PDFs/EPAR/zimulti/3956009 en.pdf.

[11] P. B. Mitchell and M. J. Morris, "Depression and anxiety with rimonabant,” The Lancet, vol. 370, no. 9600, pp. 1671-1672, 2007.

[12] Stiles, S. FDA:Excess of CV events with sibutramine in SCOUT. HeartWire News, http://www.theheart.org/article/ 1027617/print.do.

[13] I. Caterson, W. Coutinho, N. Finer et al., "Early response to sibutramine in patients not meeting current label criteria: preliminary analysis of SCOUT lead-in period," Obesity, vol. 18, no. 5, pp. 987-994, 2010.

[14] L. Van Gaal, I. Caterson, W. Coutinho et al., "on behalf of the SCOUT Investigators. Weight and blood pressure response to weight management and sibutramine in diabetic and non diabetic high-risk patients: an analysis from the 6-week lead-in period of the sibutramine cardiovascular outcomes (SCOUT) trial. Diabetes," Obesity and Metabolism, vol. 12, pp. 26-34, 2010.

[15] P. Weeke, C. Andersson, E. L. Fosbøl et al., "The weight lowering effect of sibutramine and its impact on serum lipids in cardiovascular high risk patients with and without type 2 diabetes mellitus - an analysis from the SCOUT lead-in period," BMC Endocrine Disorders, vol. 10, article 3, 2010.

[16] G. Williams, "Withdrawal of sibutramine in Europe," British Medical Journal, vol. 340, article c824, 2010.

[17] W. P.T. James, I. D. Caterson, W. Coutinho et al., "Effect of sibutramine on cardiovascular outcomes in overweight and obese subjects," The New England Journal of Medicine, vol. 363, no. 10, pp. 905-917, 2010.

[18] M. D. F. S. Barbosa and E. Celis, "Immunogenicity of protein therapeutics and the interplay between tolerance and antibody responses," Drug Discovery Today, vol. 12, no. 1516, pp. 674-681, 2007.

[19] A. N. Fabricatore, T. A. Wadden, R. H. Moore et al., "Attrition from randomized controlled trials of pharmacological weight loss agents: a systematic review and analysis: obesity Management," Obesity Reviews, vol. 10, no. 3, pp. 333-341, 2009.

[20] K. Johansson, K. Neovius, S. M. Desantis, S. Rössner, and M. Neovius, "Discontinuation due to adverse events in randomized trials of orlistat, sibutramine and rimonabant: a meta-analysis," Obesity Reviews, vol. 10, no. 5, pp. 564-575, 2009.

[21] L. McGovern, J. N. Johnson, R. Paulo et al., "Treatment of pediatric obesity: a systematic review and meta-analysis of randomized trials," Journal of Clinical Endocrinology and Metabolism, vol. 93, no. 12, pp. 4600-4605, 2008.

[22] F. L. Greenway, E. Dunayevich, G. Tollefson et al., "Comparison of combined bupropion and naltrexone therapy for obesity with monotherapy and placebo," Journal of Clinical Endocrinology and Metabolism, vol. 94, no. 12, pp. 48984906, 2009.

[23] L. J. Aronne, S. Tonstad, M. Moreno et al., "A clinical trial assessing the safety and efficacy of taranabant, a CB1R inverse agonist, in obese and overweight patients: a high-dose study," International Journal of Obesity, vol. 34, no. 5, pp. 919-935, 2010.

[24] F. J. Bermudez-Silva, M. P. Viveros, J. M. McPartland, and F. Rodriguez de Fonseca, "The endocannabinoid system, eating behavior and energy homeostasis: the end or a new 
beginning?" Pharmacology Biochemistry and Behavior, vol. 95, no. 4, pp. 375-382, 2010.

[25] M. Li and B. M. Y. Cheung, "Pharmacotherapy for obesity," British Journal of Clinical Pharmacology, vol. 68, no. 6, pp. 804-810, 2009.

[26] R. S. Padwal and S. R. Majumdar, "Drug treatments for obesity: orlistat, sibutramine, and rimonabant," The Lancet, vol. 369, no. 9555, pp. 71-77, 2007.

[27] J. F. Munro, A. C. MacCuish, E. M. Wilson, and L. J. Duncan, "Comparison of continuous and intermittent anorectic therapy in obesity," British medical journal, vol. 1, no. 5588, pp. 352-354, 1968.

[28] M. Weintraub, J. D. Hasday, A. I. Mushlin, and D. H. Lockwood, "A double-blind clinical trial in weight control. Use of fenfluramine and phentermine alone and in combination," Archives of Internal Medicine, vol. 144, no. 6, pp. 1143-1148, 1984.

[29] L. Griffen and M. Anchors, "The "phen-pro" diet drug combination is net associated with valvular heart disease," Archives of Internal Medicine, vol. 158, no. 11, pp. 1278-1279, 1998.

[30] C. K. Haddock, W. S. C. Poston, P. L. Dill, J. P. Foreyt, and M. Ericsson, "Pharmacotherapy for obesity: a quantitative analysis of four decades of published randomized clinical trials," International Journal of Obesity, vol. 26, no. 2, pp. 262273, 2002.

[31] R. H. McKay, "Long-term use of diethylpropion in obesity," Current Medical Research and Opinion, vol. 1, no. 8, pp. 489493, 1973.

[32] C. Cercato, V. A. Roizenblatt, C. C. Leança et al., "A randomized double-blind placebo-controlled study of the long-term efficacy and safety of diethylpropion in the treatment of obese subjects," International Journal of Obesity, vol. 33, no. 8, pp. 857-865, 2009.

[33] A. S. Garfield and L. K. Heisler, "Pharmacological targeting of the serotonergic system for the treatment of obesity," Journal of Physiology, vol. 587, no. 1, pp. 49-60, 2009.

[34] L. K. Heisler, M. A. Cowley, L. H. Tecott et al., "Activation of central melanocortin pathways by fenfluramine," Science, vol. 297, no. 5581, pp. 609-611, 2002.

[35] L. K. Heisler, N. Pronchuk, K. Nonogaki et al., "Serotonin activates the hypothalamic-pituitary-adrenal axis via serotonin 2C receptor stimulation," Journal of Neuroscience, vol. 27, no. 26, pp. 6956-6964, 2007.

[36] D. D. Lam, M. J. Przydzial, S. H. Ridley et al., "Serotonin 5-HT2C receptor agonist promotes hypophagia via downstream activation of melanocortin 4 receptors," Endocrinology, vol. 149, no. 3, pp. 1323-1328, 2008.

[37] A. Carvajal, J. Garcia del Pozo, I. Martin de Diego, A. M. Rueda de Castro, and A. Velasco, "Efficacy of fenfluramine and dexfenfluramine in the treatment of obesity: a metaanalysis," Methods and Findings in Experimental and Clinical Pharmacology, vol. 22, no. 5, pp. 285-290, 2000.

[38] B. Guy-Grand, M. Appelbaum, G. Crepaldi, A. Gries, P. Lefebvre, and P. Turner, "International trial of long-term dexfenfluramine in obesity," The Lancet, vol. 2, no. 8672, pp. 1142-1145, 1989.

[39] E. M. H. Mathus-Vliegen, K. van de Voorde, A. M. E. Kok, and A. M. A. Res, "Dexfenfluramine in the treatment of severe obesity: a placebo-controlled investigation of the effects on weight loss, cardiovascular risk factors, food intake and eating behaviour," Journal of Internal Medicine, vol. 232, no. 2, pp. 119-127, 1992.
[40] M. Weintraub, "Long-term weight control: the National Heart, Lung, and Blood Institute funded multimodal intervention study: introduction," Clinical Pharmacology and Therapeutics, vol. 51, no. 5, pp. 581-585, 1992.

[41] R. Bowen, A. Glicklich, M. Khan et al., "Cardiac valvulopathy associated with exposure fenfluramine or dexfenfluramine: US Department of Health and Human Services Interim Public Health Recommendations, November 1997," MMWR, vol. 46, no. 45, pp. 1061-1066, 1997.

[42] G. D. Curfman, "Diet pills redux," The New England Journal of Medicine, vol. 337, no. 9, pp. 629-630, 1997.

[43] M. Delcroix, X. Kurz, D. Walckiers, M. Demedts, and R. Naeije, "High incidence of primary pulmonary hypertension associated with appetite suppressants in Belgium," European Respiratory Journal, vol. 12, no. 2, pp. 271-276, 1998.

[44] L. R. Levine, G. G. Enas, W. L. Thompson et al., "Use of fluoxetine, a selective serotonin-uptake inhibitor, in the treatment of obesity: a dose-response study," International Journal of Obesity, vol. 13, no. 5, pp. 635-645, 1989.

[45] G. A. Bray, "Use and abuse of appetite-suppressant drugs in the treatment of obesity," Annals of Internal Medicine, vol. 119, no. 7, pp. 707-713, 1993.

[46] D. J. Goldstein, A. H. Rampey, G. G. Enas et al., "Fluoxetine: a randomised clinical trial in the treatment of obesity," International Journal of Obesity, vol. 18, pp. 129-135, 1994.

[47] S. D. Wise, "Clinical studies with fluoxetine in obesity," American Journal of Clinical Nutrition, vol. 55, no. 1, pp. 181S-184S, 1992.

[48] L. L. Darga, L. Carroll-Michals, S. J. Botsford, and C. P. Lucas, "Fluoxetine's effect on weight loss in obese subjects," American Journal of Clinical Nutrition, vol. 54, no. 2, pp. 321325, 1991.

[49] F. Pedrinola, C. Sztejnsznajd, N. Lima, A. Halpern, and G. Medeiros-Neto, "The addition of dexfenfluramine to fluoxetine in the treatment of obesity: a randomized clinical trial," Obesity Research, vol. 4, no. 6, pp. 549-554, 1996.

[50] M. Anchors, "Fluoxetine is a safer alternative to fenfluramine in the medical treatment of obesity," Archives of Internal Medicine, vol. 157, no. 11, p. 1270, 1997.

[51] L. D. Whigham, N. V. Dhurandhar, P. S. Rahko, and R. L. Atkinson, "Comparison of combinations of drugs for treatment of obesity: body weight and echocardiographic status," International Journal of Obesity, vol. 31, no. 5, pp. 850-857, 2007.

[52] R. A. Plodkowski, Q. Nguyen, U. Sundaram, L. Nguyen, D. L. Chau, and S. St Jeor, "Bupropion and naltrexone: a review of their use individually and in combination for the treatment of obesity," Expert Opinion on Pharmacotherapy, vol. 10, no. 6, pp. 1069-1081, 2009.

[53] J. W. Anderson, F. L. Greenway, K. Fujioka, K. M. Gadde, J. McKenney, and P. M. O'Neil, “Bupropion SR enhances weight loss: a 48-week double-blind, placebo-controlled trial," Obesity Research, vol. 10, no. 7, pp. 633-641, 2002.

[54] H. Croft, T. Houser, R. Leadbetter, and B. Jamerson, "Effect of bupropion SR on weight in the long-term treatment of depression," Obesity Research, vol. 8, supplement 1, p. 10, 2000.

[55] K. M. Gadde, C. B. Parker, L. G. Maner et al., "Bupropion for weight loss: an investigation of efficacy and tolerability in overweight and obese women," Obesity Research, vol. 9, no. 9, pp. 544-551, 2001.

[56] Z. Li, M. Maglione, W. Tu et al., "Meta-analysis: pharmacologic treatment of obesity," Annals of Internal Medicine, vol. 142, no. 7, pp. 532-546, 2005. 
[57] R. Padwal, S. K. Li, and D. C. Lau, "Long-term pharmacotherapy for obesity and overweight," Cochrane Database of Systematic Reviews, vol. 4, no. 3, Article ID CD004094, 2004.

[58] D. Rucker, R. Padwal, S. K. Li, C. Curioni, and D. C. W. Lau, "Long term pharmacotherapy for obesity and overweight: updated meta-analysis," British Medical Journal, vol. 335, no. 7631, pp. 1194-1199, 2007.

[59] M. Neovius, K. Johansson, and S. Rössner, "Head-to-head studies evaluating efficacy of pharmaco-therapy for obesity: a systematic review and meta-analysis," Obesity Reviews, vol. 9, no. 5, pp. 420-427, 2008.

[60] C. Curioni and C. André, "Rimonabant for overweight or obesity," Cochrane Database of Systematic Reviews, no. 4, Article ID CD006162, 2006.

[61] J. Hauptman, C. Lucas, M. N. Boldrin, H. Collins, and K. R. Segal, "Orlistat in the long-term treatment of obesity in primary care settings," Archives of Family Medicine, vol. 9, no. 2, pp. 160-167, 2000.

[62] S. B. Heymsfield, K. R. Segal, J. Hauptman et al., "Effects of weight loss with orlistat on glucose tolerance and progression to type 2 diabetes in obese adults," Archives of Internal Medicine, vol. 160, no. 9, pp. 1321-1326, 2000.

[63] S. Rössner, L. Sjöström, R. Noack, A. E. Meinders, and G. Noseda, "Weight loss, weight maintenance, and improved cardiovascular risk factors after 2 years treatment with orlistat for obesity," Obesity Research, vol. 8, no. 1, pp. 49-61, 2000.

[64] J. S. Torgerson, J. Hauptman, M. N. Boldrin, and L. Sjöström, "XENical in the Prevention of Diabetes in Obese Subjects (XENDOS) Study: a randomized study of orlistat as an adjunct to lifestyle changes for the prevention of type 2 diabetes in obese patients," Diabetes Care, vol. 27, no. 1, pp. 155-161, 2004.

[65] K. Horvath, K. Jeitler, U. Siering et al., "Long-term effects of weight-reducing interventions in hypertensive patients: systematic review and meta-analysis," Archives of Internal Medicine, vol. 168, no. 6, pp. 571-580, 2008.

[66] A. Siebenhofer, K. Horvath, K. Jeitler et al., "Long-term effects of weight-reducing drugs in hypertensive patients," Cochrane Database of Systematic Reviews, no. 3, Article ID CD007654, 2009.

[67] M. J. Franz, J. J. VanWormer, A. L. Crain et al., "Weight-loss outcomes: a systematic review and meta-analysis of weightloss clinical trials with a minimum 1-year follow-up," Journal of the American Dietetic Association, vol. 107, no. 10, pp. 1755-1767, 2007.

[68] B. Hutton and D. Fergusson, "Changes in body weight and serum lipid profile in obese patients treated with orlistat in addition to a hypocaloric diet: a systematic review of randomized clinical trials," American Journal of Clinical Nutrition, vol. 80, no. 6, pp. 1461-1468, 2004.

[69] S. O’Meara, R. Riemsma, L. Shirran, L. Mather, and G. Ter Riet, "A systematic review of the clinical effectiveness of orlistat used for the management of obesity," Obesity Reviews, vol. 5, no. 1, pp. 51-68, 2004.

[70] R. Padwal, S. K. Li, and D. C.W. Lau, "Long-term pharmacotherapy for overweight and obesity: a systematic review and meta-analysis of randomized controlled trials," International Journal of Obesity, vol. 27, no. 12, pp. 1437-1446, 2003.

[71] S. Czernichow, C. M.Y. Lee, F. Barzi et al., "Efficacy of weight loss drugs on obesity and cardiovascular risk factors in obese adolescents: a meta-analysis of randomized controlled trials," Obesity Reviews, vol. 11, no. 2, pp. 150-158, 2010.
[72] FDA Drug Safety Communication: Completed safety review of Xenical/Alli (orlistat) and severe liver injury, 2010, http://www.fda.gov/Drugs/DrugSafety/PostmarketDrugSafetyInformationforPatientsandProviders/DrugSafetyInformationforHeathcareProfessionals/ucm179166.htm.

[73] I. P. Connoley, Y.-L. Liu, I. Frost, I. P. Reckless, D. J. Heal, and M. J. Stock, "Thermogenic effects of sibutramine and its metabolites," British Journal of Pharmacology, vol. 126, no. 6, pp. 1487-1495, 1999.

[74] S. P. Jones, I. G. Smith, F. Kelly, and J. A. Gray, "Long term weight loss with sibutramine," International Journal of Obesity, vol. 19, supplement 2, p. 41, 1995.

[75] M. Apfelbaum, P. Vague, O. Ziegler, C. Hanotin, F. Thomas, and E. Leutenegger, "Long-term maintenance of weight loss after a very-low-calorie diet: a randomized blinded trial of the efficacy and tolerability of sibutramine," American Journal of Medicine, vol. 106, no. 2, pp. 179-184, 1999.

[76] G. A. Bray, D. H. Ryan, D. Gordon, S. Heidingsfelder, F. Cerise, and K. Wilson, "A double-blind randomized placebocontrolled trial of sibutramine," Obesity Research, vol. 4, no. 3, pp. 263-270, 1996.

[77] I. G. Smith and M. A. Goulder, "Randomized placebocontrolled trial of long-term treatment with sibutramine in mild to moderate obesity," Journal of Family Practice, vol. 50, no. 6, pp. 505-512, 2001.

[78] W. P. T. James, A. Astrup, N. Finer et al., "Effect of sibutramine on weight maintenance after weight loss: a randomised trial," The Lancet, vol. 356, pp. 2119-2125, 2000.

[79] F. G. McMahon, K. Fujioka, B. N. Singh et al., "Efficacy and safety of sibutramine in obese white and African American patients with hypertension: a 1-year, double-blind, placebocontrolled, multicenter trial," Archives of Internal Medicine, vol. 160, no. 14, pp. 2185-2191, 2000.

[80] I. G. Smith, S. P. Jones, M. J. Heath, and F. Kelly, "Categorical outcome analysis of weight loss in long-term sibutramine," International Journal of Obesity, vol. 20, p. 157, 1996.

[81] K. Johansson, J. Sundström, K. Neovius, S, Rössner, and M. Neovius, "Long-term changes in blood pressure following orlistat and sibutramine treatment: a meta-analysis," Obesity Reviews, vol. 11, no. 11, pp. 777-791, 2009.

[82] T. A. Wadden, R. I. Berkowitz, D. B. Sarwer, R. PrusWisniewski, and C. Steinberg, "Benefits of lifestyle modification in the pharmacologic treatment of obesity: a randomized trial," Archives of Internal Medicine, vol. 161, no. 2, pp. 218-227, 2001.

[83] T. A. Wadden, R. I. Berkowitz, L. G. Womble, D. B. Sarwer, M. E. Arnold, and C. M. Steinberg, "Effects of sibutramine plus orlistat in obese women following 1 year of treatment by sibutramine alone: a placebo-controlled trial," Obesity Research, vol. 8, no. 6, pp. 431-437, 2000.

[84] R. Sari, M. K. Balci, M. Cakir, H. Altunbas, and U. Karayalcin, "Comparison of efficacy of sibutramine or orlistat versus their combination in obese women," Endocrine Research, vol. 30, no. 2, pp. 159-167, 2004.

[85] L. J. Aronne, A. E. Halseth, C. M. Burns, S. Miller, and L. Z. Shen, "Enhanced weight loss following coadministration of pramlintide with sibutramine or phentermine in a multicenter trial," Obesity, vol. 18, no. 9, pp. 1739-1746, 2010.

[86] W. P. T. James, "The SCOUT study: risk-benefit profile of sibutramine in overweight high-risk cardiovascular patients," European Heart Journal, Supplement, vol. 7, pp. L44-L48, 2005. 
[87] A. M. Sharma, I. D. Caterson, W. Coutinho et al., "Blood pressure changes associated with sibutramine and weight management-an analysis from the 6-week lead-in period of the sibutramine cardiovascular outcomes trial (SCOUT)," Diabetes, Obesity and Metabolism, vol. 11, no. 3, pp. 239-250, 2009.

[88] S. Von Haehling, M. Lainscak, and S. D. Anker, "Sibutramine in cardiovascular disease: is SCOUT the new STORM on the horizon?" European Heart Journal, vol. 28, no. 23, pp. 28302831, 2007.

[89] C. Torp-Pedersen, I. Caterson, W. Coutinho et al., "Cardiovascular responses to weight management and sibutramine in high-risk subjects: an analysis from the SCOUT trial," European Heart Journal, vol. 28, no. 23, pp. 2915-2923, 2007.

[90] GLG Expert Contributor. New Meridia SCOUT trial has major implications for obesity drug development, 2009, http://www.glgroup.com/News/New-Meridia-SCOUT-Trialhas-Major-Implications-for-Obesity-Drug-Development45006.html.

[91] FDA Drug Safety Communication: Follow-Up to the November 2009 Early Communication about an Ongoing Safety Review of Sibutramine, Marketed as Meridia, 2010, http://www.fda.gov/Drugs/DrugSafety/PostmarketDrugSafetyInformationforPatientsandProviders/DrugSafetyInformationforHeathcareProfessionals/ucm 198206.htm.

[92] N. Singer and A. Pollack, Heart Patients Warned Against Using Meridia, an Anti-Obesity Drug. The New York Times, 2010, http://www.nytimes.com/2010/01/23/business/ 23diet.html.

[93] M. Harrison-Woolrych, J. Ashton, and P. Herbison, "Fatal and non-fatal cardiovascular events in a general population prescribed sibutramine in New Zealand: a prospective cohort study," Drug Safety, vol. 33, no. 7, pp. 605-613, 2010.

[94] A. Astrup, "Drug management of obesity—efficacy versus safety," The New England Journal of Medicine, vol. 363, no. 3, pp. 288-290, 2010.

[95] K. Cahill and M. Ussher, "Cannabinoid type 1 receptor antagonists (rimonabant) for smoking cessation," Cochrane Database of Systematic Reviews, no. 4, Article ID CD005353, 2007.

[96] L. Van Gaal, X. Pi-Sunyer, J. P. Després, C. McCarthy, and A. Scheen, "Efficacy and safety of rimonabant for improvement of multiple cardiometabolic risk factors in overweight/obese patients: pooled 1-year data from the Rimonabant in Obesity (RIO) program," Diabetes care, vol. 31, supplement 2, pp. S229-240, 2008.

[97] K. Fujioka, C. Apovian, and J. Hill, The Evolution of Obesity Therapies: New Applications for Existing Drugs. MedscapeCME Diabetes Endocrinology, 2010, http://cme.medscape.com/viewarticle/722366.

[98] S. E. Nissen, S. J. Nicholls, K. Wolski et al., "Effect of rimonabant on progression of atherosclerosis in patients with abdominal obesity and coronary artery disease: the STRADIVARIUS randomized controlled trial," JAMA, vol. 299, no. 13, pp. 1547-1560, 2008.

[99] A. Astrup, S. Madsbad, L. Breum, T. Jensen, J. Kroustrup, and T. Larsen, "Effect of tesofensine on bodyweight loss body composion and quality of life in obese patients: a randomised, double-blind, placebo-controlled trial," The Lancet, vol. 372, pp. 1906-1913, 2008.

[100] N. C. Chavez-Tapia, F. I. Tellez-Avila, G. Bedogni, L. S. Crocè, F. Masutti, and C. Tiribelli, "Systematic review and metaanalysis on the adverse events of rimonabant treatment: considerations for its potential use in hepatology," $B M C$ Gastroenterology, vol. 9, article no. 1471, p. 75, 2009.

[101] E. Berton and R. Bender, UPDATE: Sanofi-Aventis stops all Acomplia clinical trials. Dow Jones Newswires, 2008, www.djnewswires.com.

[102] K. M. McTigue, R. Hess, and J. Ziouras, "Obesity in older adults: a systematic review of the evidence for diagnosis and treatment," Obesity, vol. 14, no. 9, pp. 1485-1497, 2006.

[103] H. Oude Luttikhuis, L. Baur, H. Jansen et al., "Interventions for treating obesity in children," Cochrane Database of Systematic Reviews, no. 1, Article ID CD001872, 2009.

[104] R. M. Viner, Y. Hsia, T. Tomsic, and I. C.K. Wong, "Efficacy and safety of anti-obesity drugs in children and adolescents: systematic review and meta-analysis: obesity management," Obesity Reviews, vol. 11, no. 8, pp. 593-602, 2010.

[105] K. M. Gadde and D. B. Allison, "Combination pharmaceutical therapies for obesity," Expert Opinion on Pharmacotherapy, vol. 10, no. 6, pp. 921-925, 2009.

[106] M. A. Valentino, J. E. Lin, and S. A. Waldman, "Central and peripheral molecular targets for antiobesity pharmacotherapy," Clinical Pharmacology and Therapeutics, vol. 87, no. 6, pp. 652-662, 2010.

[107] L. Aronne, K. Fujioka, V. Aroda et al., "Progressive reduction in body weight after treatment with the amylin analog pramlintide in obese subjects: a phase 2, randomized, placebo-controlled, dose-escalation study," Journal of Clinical Endocrinology and Metabolism, vol. 92, no. 8, pp. 2977-2983, 2007.

[108] S. R. Smith, L. J. Aronne, C. M. Burns, N. C. Kesty, A. E. Halseth, and C. Weyer, "Sustained weight loss following 12-month pramlintide treatment as an adjunct to lifestyle intervention in obesity," Diabetes Care, vol. 31, no. 9, pp. 1816-1823, 2008.

[109] T. Vilsbøll, M. Zdravkovic, T. Le-Thi et al., "Liraglutide, a long-acting human glucagon-like peptide-1 analog, given as monotherapy significantly improves glycemic control and lowers body weight without risk of hypoglycemia in patients with type 2 diabetes," Diabetes Care, vol. 30, no. 6, pp. 16081610, 2007.

[110] S. Madsbad, "Liraglutide effect and action in diabetes (LEAD) trial," Expert Review of Endocrinology and Metabolism, vol. 4, no. 2, pp. 119-129, 2009.

[111] M. Nauck, A. Frid, K. Hermansen et al., "Efficacy and safety comparison of liraglutide, glimepiride, and placebo, all in combination with metformin, in type 2 diabetes," Diabetes Care, vol. 32, no. 1, pp. 84-90, 2009.

[112] A. Astrup, S. Rössner, L. Van Gaal et al., "Effects of liraglutide in the treatment of obesity: a randomised, double-blind, placebo-controlled study," The Lancet, vol. 374, no. 9701, pp. 1606-1616, 2009.

[113] L. T. Meade, "Practical use of exenatide and pramlintide for the treatment of type 2 diabetes," Journal of Pharmacy Practice, vol. 22, no. 6, pp. 540-545, 2009.

[114] L. Blonde, E. J. Klein, J. Han et al., "Interim analysis of the effects of exenatide treatment on A1C, weight and cardiovascular risk factors over 82 weeks in 314 overweight patients with type 2 diabetes," Diabetes, Obesity and Metabolism, vol. 8, no. 4, pp. 436-447, 2006.

[115] C. Addy, H. Wright, K. Van Laere et al., "The acyclic CB1R inverse agonist taranabant mediates weight loss by increasing energy expenditure and decreasing caloric intake," Cell Metabolism, vol. 7, no. 1, pp. 68-78, 2008. 
[116] T. A. Wadden, K. Fujioka, S. Toubro et al., "A randomized trial of lifestyle modification and taranabant for maintaining weight loss achieved with a low-calorie diet," Obesity, vol. 18, no. 12, pp. 2301-2310, 2010.

[117] M. S. Kipnes, P. Hollander, K. Fujioka et al., "A one-year study to assess the safety and efficacy of the CB1R inverse agonist taranabant in overweight and obese patients with type 2 diabetes," Diabetes, Obesity and Metabolism, vol. 12, no. 6, pp. 517-531, 2010.

[118] J. Proietto, A. Rissanen, J. B. Harp et al., "A clinical trial assessing the safety and efficacy of the CB1R inverse agonist taranabant in obese and overweight patients: lowdose study," International Journal of Obesity, vol. 34, no. 8, pp. 1243-1254, 2010.

[119] L. Koch, "Obesity: taranabant no longer developed as an antiobesity agent," Nature Reviews Endocrinology, vol. 6, no. 6, p. 300, 2010.

[120] S. R. Smith, N. J. Weissman, and C. M. Anderson, "Multicentre placebo-controlled trial of lorcaserin for weight management," The New England Journal of Medicine, vol. 363, pp. 245-256, 2010.

[121] T. A. Wadden, J. P. Foreyt, and G. D. Foster, "Weight loss with naltrexone sr/bupropion SR combination therapy as an adjunct to behavior modification: the COR-BMOD Trial," Obesity, 2010. In press.

[122] J. Rosenstock, P. Hollander, K. M. Gadde, X. Sun, R. Strauss, and A. Leung, "A randomized, double-blind, placebocontrolled, multicenter study to assess the efficacy and safety of topiramate controlled release in the treatment of obese type 2 diabetic patients," Diabetes Care, vol. 30, no. 6, pp. 1480-1486, 2007.

[123] Vivus Inc. VIVUS Announces Positive Results From Two Phase 3 Studies: Obese Patients on Qnexa Achieve Average Weight Loss up to $14.7 \%$ and Significant Improvements in Co-Morbidities: Results of EQUIP and CONQUER Phase 3 Studies Exceed FDA Benchmarks for Obesity Treatments, Demonstrate Positive Safety Profile, http://ir.vivus.com/releasedetail.cfm?ReleaseID $=407933$.

[124] H. M. Connolly, J. L. Crary, M. D. McGoon et al., "Valvular heart disease associated with fenfluramine phentermine," The New England Journal of Medicine, vol. 337, no. 9, pp. 581588, 1997.

[125] R. Chakrabarti, "Pharmacotherapy of obesity: emerging drugs and targets," Expert Opinion on Therapeutic Targets, vol. 13, no. 2, pp. 195-207, 2009.

[126] E. Idelevich, W. Kirch, and C. Schindler, "Current pharmacotherapeutic concepts for the treatment of obesity in adults," Therapeutic Advances in Cardiovascular Disease, vol. 3, no. 1, pp. 75-90, 2009.

[127] C. M. Anderson, M. Sanchez, J. Krolikowski, M. Mancini, and W. R. Shanahan, a selective 5-HT2C agonist is efficacious for weight loss across patient subgroups. American Diabetes Association 70th Scientific Meeting. Abstract 1845P, 2010, http://professional.diabetes.org/Abstracts_Display .aspx?TYP=1\&CID=80762.

[128] M. C. Fidler, M. Sanchez, B. L. Raether, C. M. Anderson, and W. R. Shanahan, Changes in glucose tolerance and cardiovascular risk factors after 52 weeks of treatment with lorcaserin. American Diabetes Association 70th Scientific Meeting. Abstract 1855-P, 2010, http://professional.diabetes.org/Abstracts_Display.aspx?TYP $=1 \& \mathrm{CID}=80772$.
[129] A. Astrup, D. H. Meier, B. O. Mikkelsen, J. S. Villumsen, and T. M. Larsen, "Weight loss produced by tesofensine in patients with Parkinson's or Alzheimer's disease," Obesity, vol. 16, no. 6, pp. 1363-1369, 2008.

[130] S. G. Holtzman, "Suppression of appetitive behavior in the rat by naloxone: lack of effect of prior morphine dependence," Life Sciences, vol. 24, no. 3, pp. 219-226, 1979.

[131] R. L. Atkinson, L. K. Berke, and C. R. Drake, "Effects of longterm therapy with naltrexone on body weight in obesity," Clinical Pharmacology and Therapeutics, vol. 38, no. 4, pp. 419-422, 1985.

[132] M. Bertino, G. K. Beauchamp, and K. Engelman, "Naltrexone, an opioid blocker, alters taste perception and nutrient intake in humans," American Journal of Physiology, vol. 261, no. 1, pp. R59-R63, 1991.

[133] R. Malcolm, P. M. O’Neil, and J. D. Sexauer, “A controlled trial of naltrexone in obese humans," International Journal of Obesity, vol. 9, no. 5, pp. 347-353, 1985.

[134] T. A. Spiegel, A. J. Stunkard, and E. E. Shrager, "Effect of Naltrexone on food intake, hunger, and satiety in obese men," Physiology and Behavior, vol. 40, no. 2, pp. 135-141, 1987.

[135] R. D. Cone, "Anatomy and regulation of the central melanocortin system," Nature Neuroscience, vol. 8, no. 5, pp. 571-578, 2005.

[136] H. C. Grossman, M. M. Hadjimarkou, R. M. Silva et al., "Interrelationships between mu opiod and melanocortin receptors in mediating food intake in rats," Brain Research, vol. 991, pp. 240-244, 2003.

[137] R. Kusher, "Anti-obesity drugs," Expert Opinion on Pharmacotherapy, vol. 9, pp. 1339-1350, 2008.

[138] S. L. Mcelroy, A. I. Guerdjikova, A. Rosen, D. D. Kim, R. Landbloom, and E. Dunayevich, An openlabel study evaluating the naltrexone SR/bupropion SR combination therapy in overweight or obese subjects with major depression. American Diabetes Association 70th Scientific Meeting, Abstract 1851-P, 2010, http://professional.diabetes.org/Abstracts_Display.aspx?TYP $=1 \& \mathrm{CID}=80768$

[139] A. K. Gupta, P. Hollander, H. Bays et al., mproved glycemic control and weight loss with naltrexone SR/bupropion SR combination therapy in overweight/obese subjects with Type 2 Diabetes. American Diabetes Association 70th Scientific Meeting, Abstract 2633-PO, http://professional.diabetes.org/Abstracts_Display.aspx?TYP $=1 \& \mathrm{CID}=81463$.

[140] P. Hollander, R. Plodkowski, and A. K. Gupta, CORDiabetes: naltrexone SR/Bupropion SR combination therapy led to significant and sustained weight loss and improved HbAlc in overweight/obese subjects with Type 2 Diabetes. American Diabetes Association 70th Scientific Meeting, Abstract 56-OR, http://professional.diabetes .org/Abstracts_Display.aspx?TYP=1\&CID=79004.

[141] S. R. Smith, T. Church, and J. Geohas, Naltrexone SR/Bupropion SR Combination Therapy Reduces Total and Visceral Adiposity in Overweight and Obese Subjects in the COR-I Study. American Diabetes Association 70th Scientific Meeting (2010). 70th Scientific Sessions, Abstract 1848-P, http://professional.diabetes.org/Abstracts_Display.aspx?TYP $=1 \& \mathrm{CID}=80765$

[142] K. M. Gadde, G. M. Yonish, M. S. Foust, and H. R. Wagner II, "Combination therapy of zonisamide and bupropion for weight reduction in obese women: a preliminary, randomized, open-label study," Journal of Clinical Psychiatry, vol. 68, no. 8, pp. 1226-1229, 2007. 
[143] F. Greenway, J. Anderson, R. Atkinson et al., "Bupropion and zonisamide for the treatment of obesity [abstract 52-OR]," Obesity Research, vol. 14, A17, 2006.

[144] Orexigen therapeutics, http://www.orexigen.com/candidates.

[145] K. M. Gadde, D. M. Franciscy, H. R. Wagner II, and K. R. R. Krishnan, "Zonisamide for weight loss in obese adults: a randomized Controlled trial," JAMA, vol. 289, no. 14, pp. 1820-1825, 2003.

[146] K. Fujioka and M. W. Lee, "Pharmacologic treatment options for obesity: current and potential medications," Nutrition in Clinical Practice, vol. 22, no. 1, pp. 50-54, 2007.

[147] L. M. Kaplan, "Pharmacological therapies for obesity," Gastroenterology Clinics of North America, vol. 34, no. 1, pp. 91-104, 2005.

[148] A. F. D. A. Pollack, Panel Votes Against Obesity Drug. The New York Times, 2010, http://www.nytimes.com /2010/07/16/health/16obese.html?_r=1\&_r=1\&ref=food_and _drug_administration.

[149] E. Ravussin, S. R. Smith, J. A. Mitchell et al., "Enhanced weight loss with pramlintide/metreleptin: an integrated neurohormonal approach to obesity pharmacotherapy," Obesity, vol. 17, no. 9, pp. 1736-1743, 2009. 


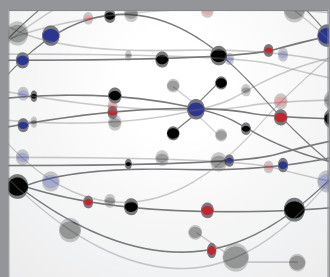

The Scientific World Journal
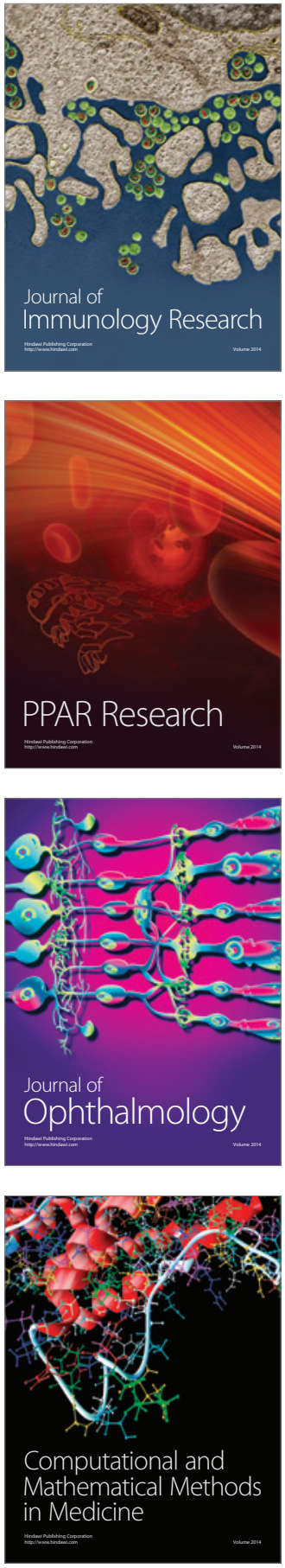

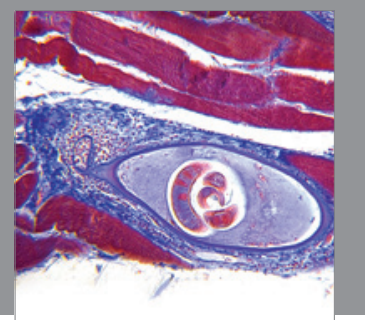

Gastroenterology

Research and Practice
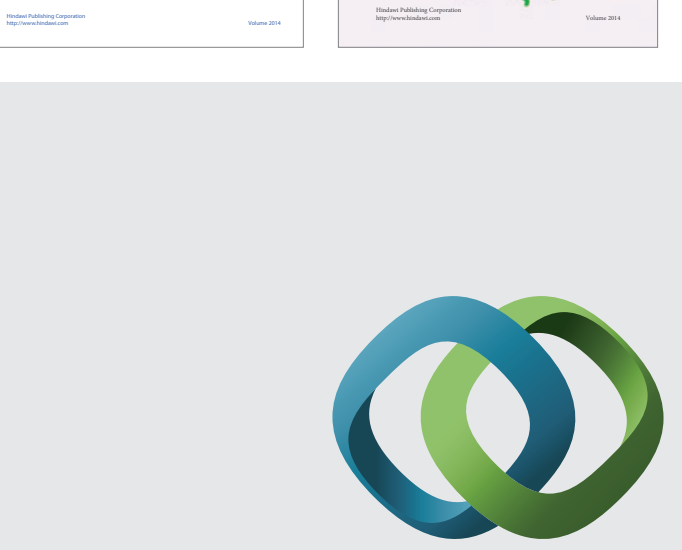

\section{Hindawi}

Submit your manuscripts at

http://www.hindawi.com
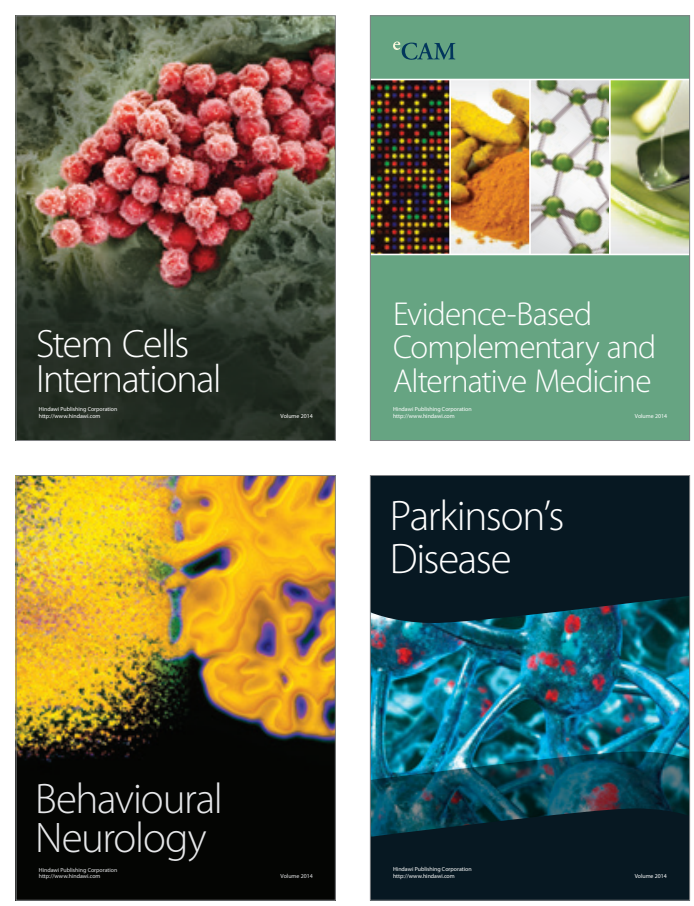

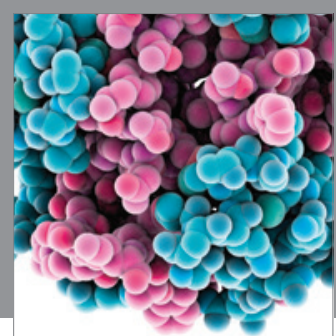

Journal of
Diabetes Research

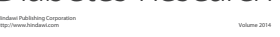

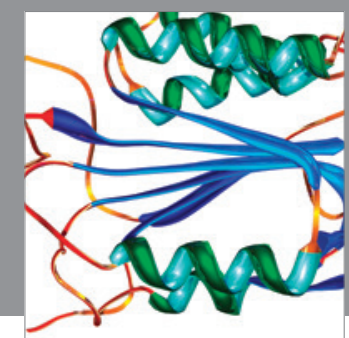

Disease Markers
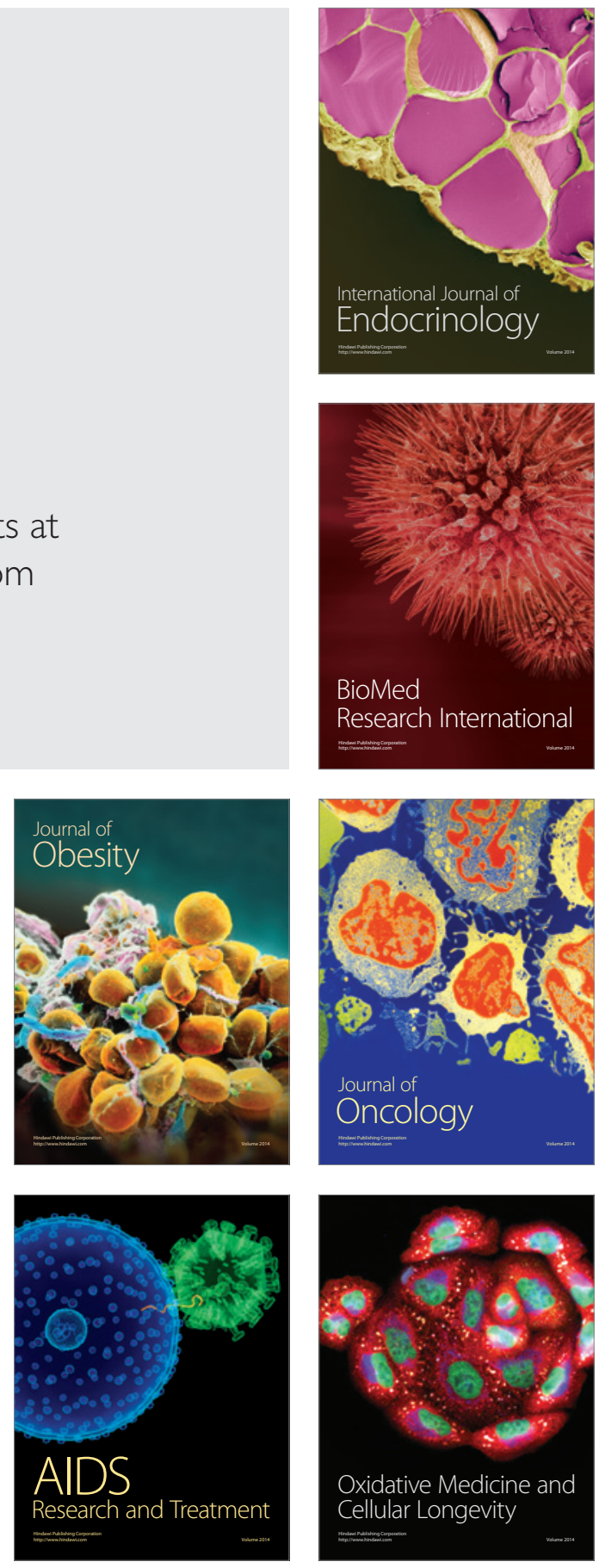